\title{
A GIS-BASED APPROACH FOR EXPLORING GEOTHERMAL RESOURCES ALONG PART OF THE KENYAN RIFT
}

*MACHARIA, M. W., GACHARI, M.K., MARIITA, N., O., MUNDIA, C.N., \&KURIA, D.N.

Dedan Kimathi University of Technology. Post Office Box 657-10100, Nyeri, Kenya.

Received :January 2018; Revised: March 2018; Accepted: April 2018

\section{ABSTRACT}

Most geothermal prospects have surface manifestations such as hot-springs, mud-pools while others have no obvious features. There are mainly two phases of exploration; reconnaissance and siting of wells when exploiting the geothermal resource. Geothermal exploration efforts are costly and are done using several methods such as geology, geophysics, geochemistry, Remote Sensing and GIS. GIS has the advantage of combining several datasets for analysis therefore achieving better results by narrowing to a target area. Remote sensing data provides a low lost methodology for deriving geothermal indicators. In this study Analytical Hierarchy Process (AHP) was used to determine geothermal potential areas using inputs from Land Surface Temperature (LST), geology, slope, drainage, land use/cover. Geothermal potential map was generated by weighting all the variables using multi criteria analysis. The map was classified into three classes; high potential, moderately potential and less potential areas. The methodology used revealed geothermal potential areas which coincide with ground survey data with over 50\% success for areas in Menengai, Eburru and Suswa. Other unexplored areas were also revealed and marked for further detailed filed survey. GIS and Remote sensing methods are powerful tools in geothermal exploration as demonstrated in this study.

Keywords: AHP, geothermal exploration, LST, environmental suitability model

*Correspondence: Mary W. Macharia, Dedan Kimathi University of Technology. Post Office Box 657-10100, Nyeri, Kenya. Email: marywandia@gmail.com

\section{INTRODUCTION}

Renewable energy has been growing steadily and in the year 2016 it accounted for 55.3\% of new electricity generating capacity added worldwide (Ren21, 2017). The contribution of renewable energy to the world's electricity is estimated to be $11.3 \%$ (Ren21, 2017). Renewable energy has prevented emission of carbon dioxide amounting to 0.7 Giga-tonnes in 2016 according to global trends in renewable energy investment 2017 report. The main renewable energy resources include geothermal, biomass, solar, wind, biofuels and ocean energy. There are several advantages associated with geothermal power such as; it is indigenous and renewable, it has high degree of availability, and it has base load power generation, reduced vulnerability to weather and climatic variations, provides clean and safe

MACHARIA, et al.: A GIS-Based Approach for Exploring Geothermal Resources Along Part of the Kenyan Rift. 


\section{Journal of Applied Sciences, Engineering and Technology for Development. Volume 2, Issue 1}

energy using little land, proven technology, flexible expansion to meet demand and direct heat applications (Macharia, et al., 2017). Kenya is set to increase the robustness and reliability of its power sector (Omenda \& Simiyu, 2015). In the last three decades Kenya has invested heavily in geothermal exploration and harvesting. The government of Kenya has provided a stable investment climate for private sector participation in energy, which has attracted several investors undertaking exploration and harvesting. The country aims at increasing electricity generation capacity to $23000 \mathrm{MW}$ by 2030 out of which $5000 \mathrm{MW}$ will be from geothermal (IREK, 2015; Omenda \& Simiyu, 2015).

GIS has been used in the past as a decision making tool in geothermal exploration with its advantage of database management, modelling of variety of data layers as well as the ability of weighting various variables using different techniques. Before geothermal wells are drilled, surface exploration is carried out to eliminate areas non geothermal areas so as to allow effort and resources to be channeled towards the high geothermal potential areas (Yalcin \& Kilic Gul, 2017). The most common method of geothermal exploration is ground surveys by geologists, geophysicists and geochemists from which they build conceptual models based on their findings (Macharia, et al., 2017).. Remote Sensing and GIS method are largely used to locate preliminary geothermal potential areas and related information on topography (Noorollahi et al., 2008). This information is used as a guide by the geo scientists when conducting detailed survey it helps them to narrow down to areas of geothermal potential in addition to providing additional information in relation to accessibility. To minimize human errors that occur when geo scientists are combining different datasets, GIS come in handy to provide the ability to handle, store and manipulate different datasets generated by different methods and provides techniques of multi criteria weighting (Reeves \& Rae, 2016; Sadeghi \& Khalajmasoumi, 2015).

GIS has been used as a decision making tool to show high priority areas for geothermal resource by weighting datasets from geology, geochemical and thermal. This was successfully applied for Akita and Iwate prefectures in northern Japan with 97\% success (Noorollahi et al., 2007). Boolean and Index Overlay GIS models were applied with datasets from geology, geochemical and geophysical to provide priority areas for geothermal well siting in North West Iran (Noorollahi et al., 2007; Tüfekçi, et al., 2010). Multi Criteria Analysis method was applied to create geothermal favourability maps in Western Anatolia. A GIS model was 


\section{Journal of Applied Sciences, Engineering and Technology for Development. Volume 2, Issue 1}

developed using Index Overlay method for Sicily southern Italy by combining geological and economic data to develop geothermal favourability maps (Trumpy et al., 2015). AHP have been used to define geothermal potential areas in Afyonkarahisar Turkey by considering proximity to hot springs, fault lines, drainage, wetlands and settlement (Yalcin \& Kilic Gul, 2017). Binary index overlay and fuzzy logic methods were used to provide preliminary information on geothermal resources by combining data on rocks, volcanoes, hotsprings and faults in North West Iran (Sadeghi \& Khalajmasoumi, 2015). In Kenya, at Menengai, GIS was used to develop conceptual model by integrating field sample datasets from geologists, geophysicists, geochemists, reservoir scientists, and environmentalist to show suitable areas for geothermal exploration drilling (Shako \& Wamalwa, 2014). GIS has also been used at Silali Kenya to locate geothermal drilling sites by using Multi Criteria Analysis to combine geochemistry data on Radon gas and carbon Dioxide, geology data on eruption centres, faults and fumaroles, heat loss data and geophysics (Wamalwa, 2011). The main objective of this study was to model heat sources using freely available datasets and using multi criteria analysis. The combination of different indicators was backed by expert's opinion to generate geothermal potential priority map.

\section{STUDY AREA}

The study area is located along the Great East African Rift System which is volcanotectonically active and is endowed with geothermal resources (Pürschel, et al., 2013). It sits on the floor of the Great Rift Valley and runs from Lake Baringo to Lake Magadi as shown in Figure 1.

Exploration in Kenya started in 1950s at Olkaria which injects close to $600 \mathrm{MW}$ to the national grid (Rotich, 2016). The status of exploration and drilling for different areas in Kenya are summarised in Table 1. Kenya has a great resource in geothermal located in the Great Rift Valley (Figure 1) and it accounts for 7 of the 15 gigawatts of potential geothermal energy in Africa (Kenya energy, 2017). Kenya has been ranked world's 8th largest producer of geothermal energy (Kenya energy, 2017). 
Journal of Applied Sciences, Engineering and Technology for Development. Volume 2, Issue 1

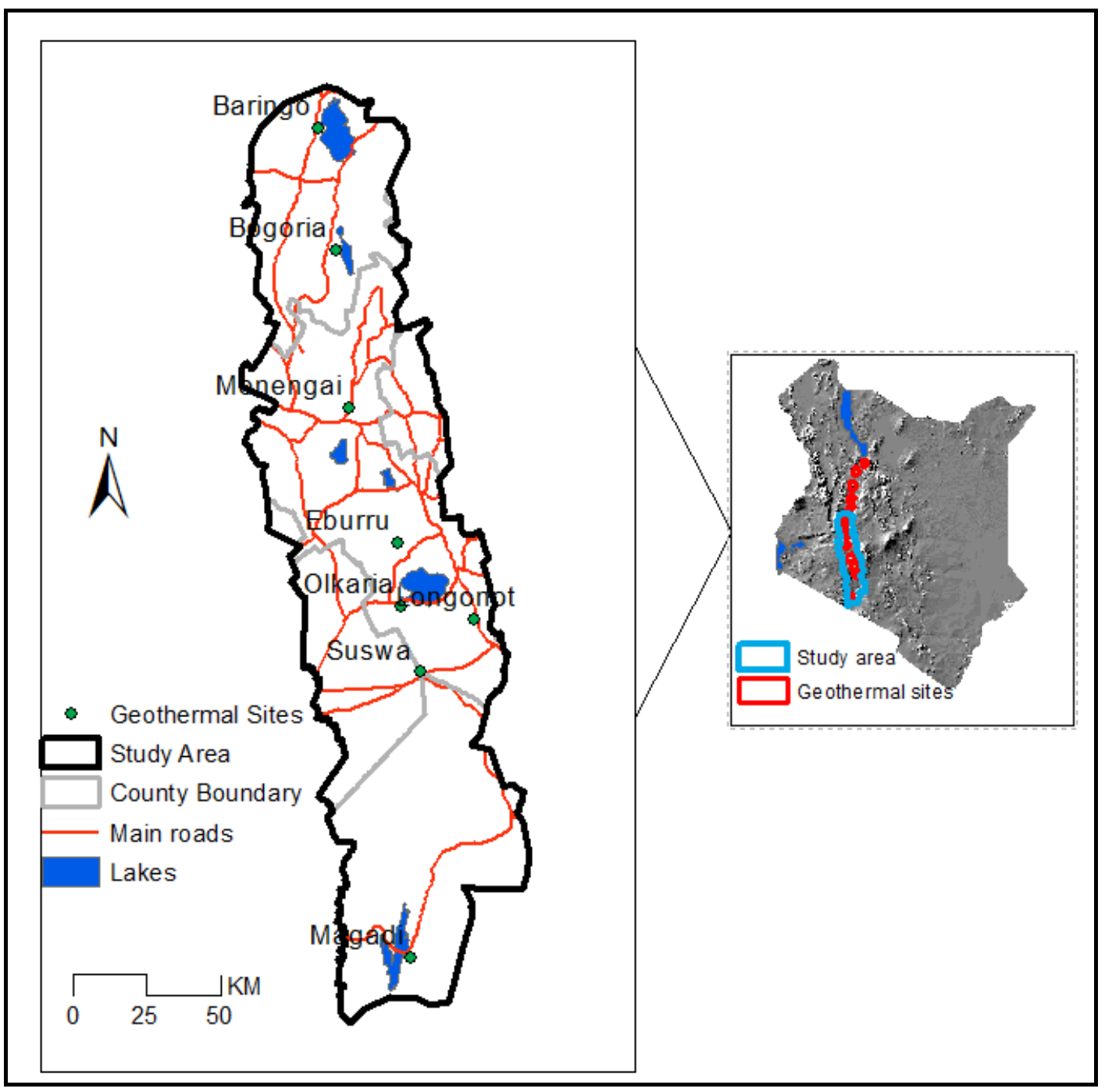

Figure 1: Location of the study area showing geothermal sites that have been investigated.

Table 1: Exploration status of geothermal prospects. Source: (Simiyu, 2010)

\begin{tabular}{ll}
\hline Prospect sites & Status \\
\hline Olkaria & $\begin{array}{l}\text { Surface exploration complete, wells sited and drilling going on, several } \\
\text { power plants in operation }\end{array}$ \\
$\begin{array}{l}\text { Longonot } \\
\text { Suswa } \\
\text { Menengai }\end{array}$ & $\begin{array}{l}\text { Surface exploration complete, wells sited and drilling not done } \\
\text { Surface exploration complete, wells sited and drilling not done }\end{array}$ \\
Badlands & Surface exploration complete, wells drilled \\
Lake Magadi, Arus, Lake & Partial Surface exploration partially, well undone, and drilling not done \\
Bogoria, Korosi, paka, & \\
Silali, Emuruangogolak, & \\
Namarunu. & \\
\hline
\end{tabular}




\section{Journal of Applied Sciences, Engineering and Technology for Development. Volume 2, Issue 1}

\section{METHOD}

Different datasets were used (Table 2). Landsat ETM+ for the year 2000 was used for computation of the LST and Land use/cover while ASTER DEM was used for slope and drainage derivation. Geology map of Kenya provided information on the geology. Ground truth data was provided by Kenya Generating Company and Geothermal Development Company for verification of the results. Questionnaires were given to experts in geothermal sector to aid in judgement while combining different datasets. MODIS LST was used to validate the Land Surface Temperatures.

Table 2: Description of datasets used for this study

\begin{tabular}{|c|c|c|}
\hline \multirow{2}{*}{$\begin{array}{l}\text { Data } \\
\text { Landsat 7ETM+Mosaic } \\
\text { (30m resolution) }\end{array}$} & \multicolumn{2}{|c|}{ Description } \\
\hline & $\begin{array}{l}\text { Path/Row } \\
169 / 060\end{array}$ & Image Acquisition Date 2000-02-12 \\
\hline & $168 / 061$ & $2000-02-21$ \\
\hline & 169/061 & $2000-02-12$ \\
\hline $\begin{array}{l}\text { ASTER Digital Elevation } \\
\text { Model(30m resolution) }\end{array}$ & \multicolumn{2}{|c|}{ Slope, drainage derivation } \\
\hline Geology $(1: 1000,000)$ & \multicolumn{2}{|c|}{ Geology map of Kenya } \\
\hline Field ground data & \multicolumn{2}{|c|}{$\begin{array}{l}\text { Include sited wells for Suswa, Menengaia and Longonot } \\
\text { coordinates. } \\
\text { Temperature point data for hot springs and mud-pools. } \\
\text { Radon gas and Carbon Dioxide data. }\end{array}$} \\
\hline MODIS & \multicolumn{2}{|c|}{ MOD11A1 V6 dated 1st March, 2000} \\
\hline
\end{tabular}

\section{Approaches used in mapping geothermal indicators}

Different methods of exploration are usually applied, including geophysical, geochemical, geological and remote sensing. First a review of different geothermal exploration techniques (Figure 2) with emphasis on remote sensing techniques especially those using satellite imagery was done (Macharia, et al., 2017). Some indicators which had high success rate in locating geothermal sites were modelled as summarized in Figure 2 with emphasis on the low cost techniques. Different imageries (Hyperspectral, multispectral) in remote sensing have been used to derive geothermal indicators satisfactorily. 


\section{Journal of Applied Sciences, Engineering and Technology for Development. Volume 2, Issue 1}

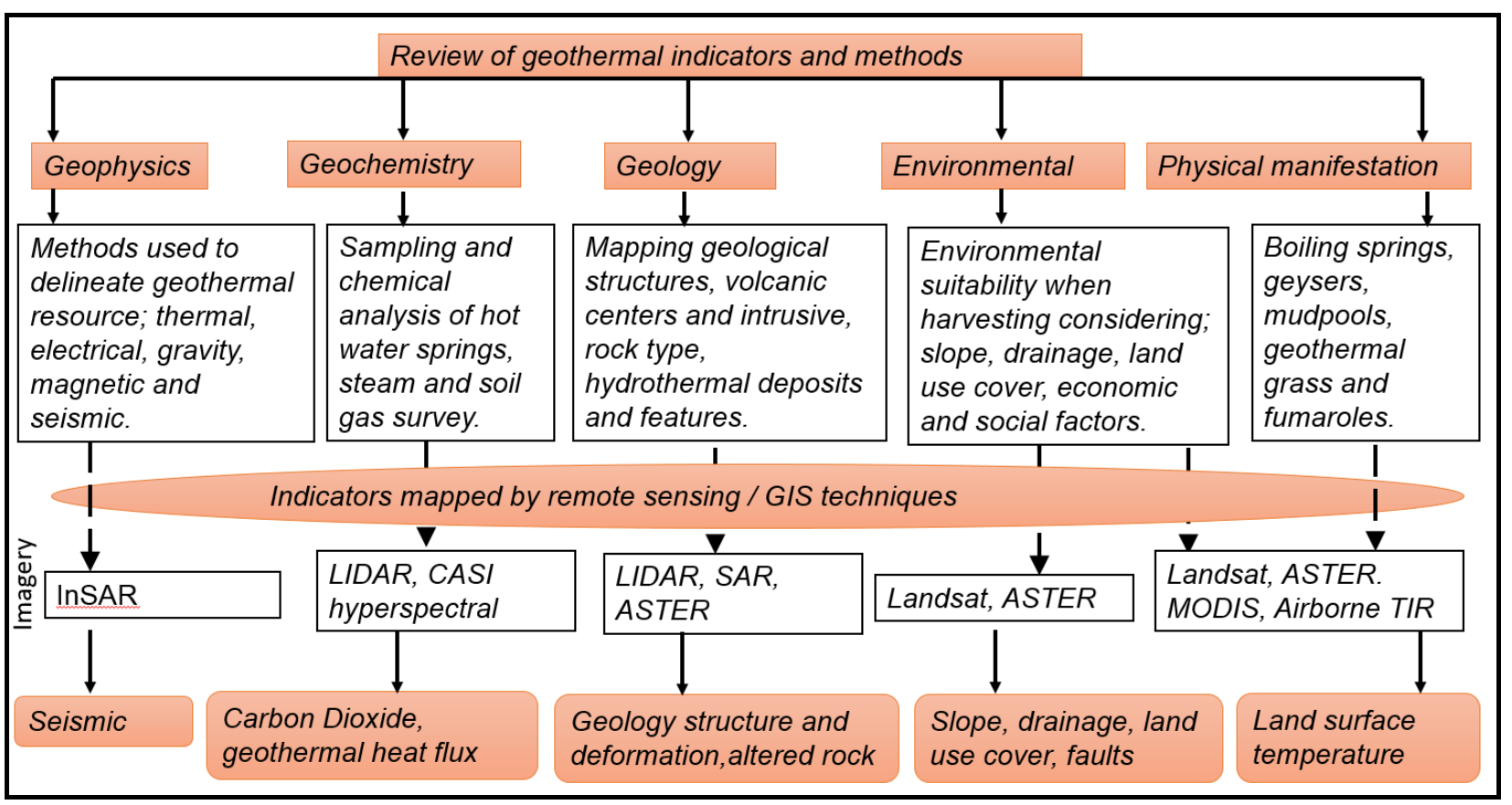

Figure 2: Flow diagram illustrating methods and indicators of geothermal energy

\section{Modelling of geothermal indicators}

In this research, slope, drainage, and LULC were considered for environmental model, LST and geology were modelled for geothermal potential areas (Figure 3). Geothermal exploration model had three sub-models; a) environmental suitability considered slope, drainage density and LULC. Slope and drainage density were generated for the Digital Elevation Model while Land use/cover was generated from the Landsat 7 ETM+, b) Land Surface Temperature (LST) was derived from Landsat thermal band, c) geology map was reclassified after digitization of the geology map of Kenya. 
Journal of Applied Sciences, Engineering and Technology for Development. Volume 2, Issue 1

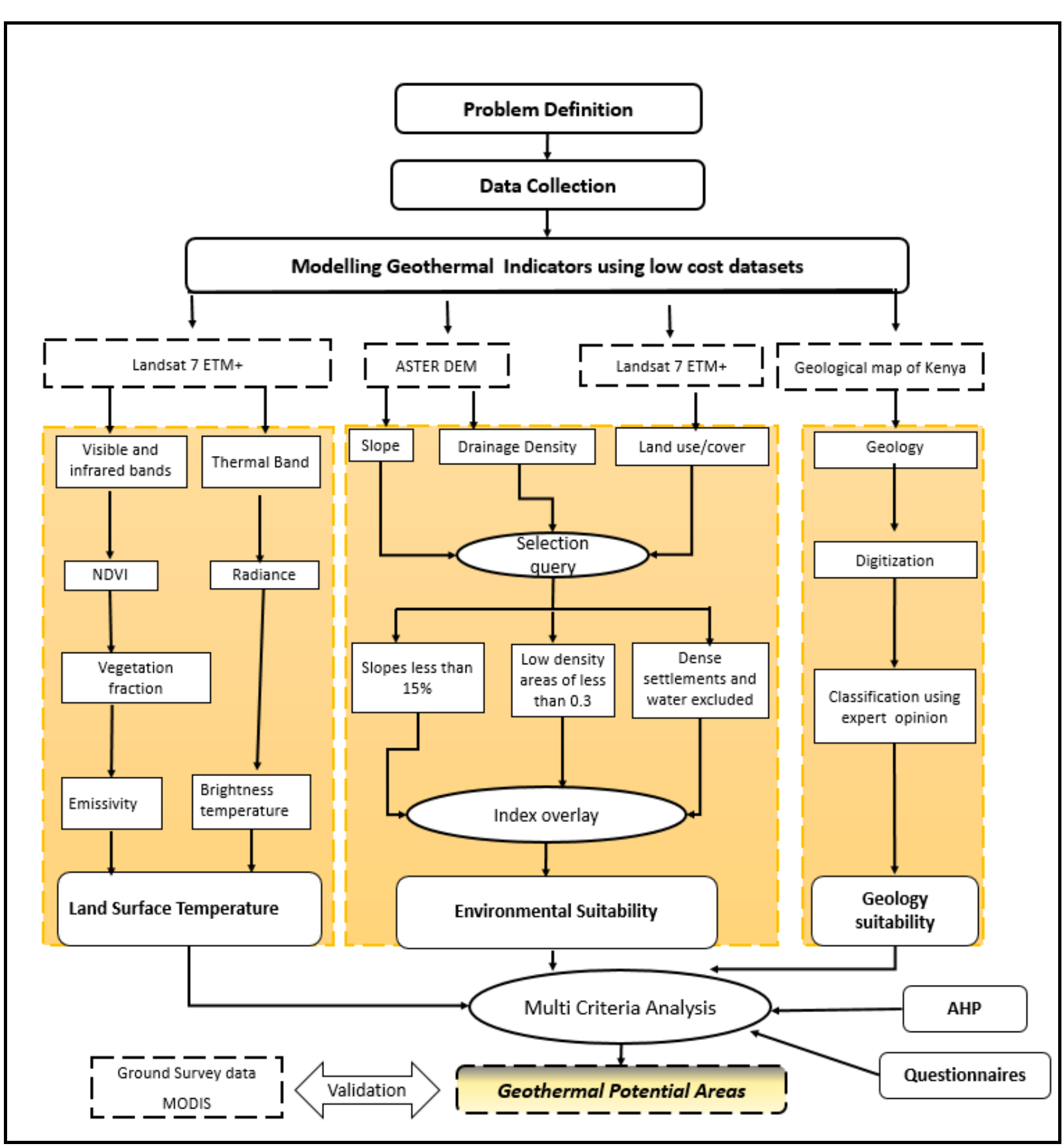

Figure 3: Methodology workflow for modelling Land Surface Temperature, Environmental Suitability and Geology.

\section{Environmental Suitability}

Topography is important when prospecting for geothermal area because of the construction and setting up of drilling equipment as well as providing access roads. Steep slopes are more expensive to level and could also create landslide problems according to (Noorollahi, et al., 


\section{Journal of Applied Sciences, Engineering and Technology for Development. Volume 2, Issue 1}

2008). The original ASTER DEM was pre-processed by identifying the sinks and later filling them. Slopes were computed from DEM and classified, areas with slope less than 15\% were considered most favourable for harvesting geothermal as shown in Figure 4a.DEM was used to delineate drainage network to eliminate areas prone to flooding. Drainage density $(D d)$ was calculated as drain lines (L) that fall within the basin boundary as well as the value for the total area of the basin (A) as per Equation 1(Yalcin and KilicGul, 2017). The drainage basin was provided by National Environment Management Authority (NEMA) and the drainage density map was classified as shown in Figure $4 \mathrm{~b}$.

Drainage Density $=D d\left(m^{-1}\right)=\frac{\sum L}{\mathbf{A}}$

Slopes and drainage layers were used as restrictive datasets. Areas with less than 15\% slope were considered more favourable for siting wells because not much drilling would be done as well as these areas would experience less soil erosion because they are not very steep. Areas with drainage density of less than 0.014 were considered not to be prone to flooding.

Land use/cover map (LULC) was generated using per pixel supervised multispectral classification using the maximum likelihood algorithm (Macharia, et al., 2013), Landsat ETM+ bands, 1, 2, 3, 4, 5 and 7 were used. To cover the whole area, three imageries were mosaicked for the year 2000 as shown in Figure 5a.

Supervised multispectral classification involved the selection of training areas representative of the 6 land cover classes as defined by Anderson et al (1976) in Table 3. The spectral signature of the training area was then used to determine which class the pixels were assigned.

\section{Land Surface temperature}

Land surface temperature is influenced by high spatial and temporal variability of surface emissivity due to the differences in surface properties, soil moisture, vegetation characteristics and surface topography. The higher water content of green vegetative cover would give a higher value for thermal emissivity resulting in greater water loss. The increase in green biomass is also often associated with greater transpiration and a larger latent heat transfer resulting in a lower surface temperature as a result of heat loss (Mia et al., 2012; Qin et al., 2011; NASA, 2009). 


\section{Journal of Applied Sciences, Engineering and Technology for Development. Volume 2, Issue 1}

Table 3: Land use/cover classes distinguished for study area based on Landsat satellite imagery: Source Anderson et al., 1976.

\begin{tabular}{|c|c|c|}
\hline & Class & Description \\
\hline 1. & BUILT-UP & $\begin{array}{l}\text { Urban or Built-up Land is comprised of areas of intensive use with much of } \\
\text { the land covered by structures. }\end{array}$ \\
\hline 2. & FOREST & $\begin{array}{l}\text { Forest of lowest disturbance level, dense canopy, as well as old secondary } \\
\text { forest. }\end{array}$ \\
\hline 3. & WATER & $\begin{array}{l}\text { Rivers, lakes, streams and Canals and other linear water bodies. Wetlands } \\
\text { and swamps are also put in this category. }\end{array}$ \\
\hline 4. & AGRICULTURAL & $\begin{array}{l}\text { Cultivated land of diverse characteristics, highly divided land with trees and } \\
\text { bushes along plot boundaries, mainly subsistence agriculture and green } \\
\text { house commercial farming, high percentage of bare ground in rotation with } \\
\text { crops. }\end{array}$ \\
\hline 5. & RANGELAND & $\begin{array}{l}\text { Bushed areas interspersed with grasses shrubs and herbs, also grassland } \\
\text { with single bushes or trees and extensive grasslands for grazing. }\end{array}$ \\
\hline 6. & OTHERS & $\begin{array}{l}\text { Barren Land is land of limited ability to support life and in which less than } \\
\text { one-third of the area has vegetation or other cover. Rocks are also put in this } \\
\text { category as well as other unclear areas. }\end{array}$ \\
\hline
\end{tabular}

Normalized Differential Vegetation Index NDVI was used to regulate near-ground surface temperature while emissivity was used to determine radiation balance at the land surface model (Zhang, et al., 2013; Mie et al., .2012; Qin et al., 2011). Before analysing results of the supervised classification, correctness of the image classification was evaluated by accuracy assessment matrix because it measures the remote sensing-based map error according to Congalton \& Green (2009). Fifty points were selected for each class. An error matrix was established (Table 6) between the map produced from classification and the reference data. According to Congalton \& Green (2009), overall accuracy of about 85\% would be significant but this can vary depending on various factors such as the level of detail or variability of the categories to be mapped.

\section{a) Radiance, reflectance and NDVI computation}

The images were converted from the measured value (Digital Number) to radiance using sensor calibration parameters provided by Landsat Hand book (NASA, 2009) as in Equation 2. This was done for band, 3, 4 and $6 \mathrm{~h}$.

Gain $* \mathrm{DN}+$ Bias $=L$ 
Where;

L spectral radiance measured over spectral bandwidth of a channel

DN digital number value recorded

Gain $(\operatorname{Lmax}-\mathrm{Lmin}) / 255$

Bias Lmin

Lmax radiance measured at detector saturation in $\mathrm{mWcm}^{-2} \mathrm{sr}^{-1}$

Lmin lowest radiance measured by detector in $\mathrm{mWcm}^{-2} \mathrm{sr}^{-1}$.

Reflectance was calculated for band 3 and 4 as per Equation 3 which was used in computation of Normalized Differential Vegetation Index (NDVI) Equation 3 and 4. Exo-atmospheric irradiance values and Earth-sun distance correction are available from Landsat Hand book (NASA, 2009).

$\rho=\frac{\pi d^{2} L}{E \cos \theta s}$

Where;

$\rho \quad$ reflectance as a function of bandwidth

d Earth-sun distance correction

$\mathrm{L}$ radiance as a function of bandwidth

E exo-atmospheric irradiance

$\theta$ s solar zenith angle

Equation 4 was used to compute NDVI from ETM+ data (Lillesand et al., 2008):

$$
N D V I=\frac{\text { Rnir }- \text { Rred }}{\text { Rnir }+ \text { Rred }}
$$

Where;

$\mathrm{R}_{\text {nir }} \quad$ reflectance measured in the near infrared

$\mathrm{R}_{\text {red }} \quad$ reflectance in the red waveband

The NDVI value ranges from -1 to +1 . NDVI values of mixed vegetation are around 0 , pure soil has negative values and pure vegetation has higher values. Using the spatial analyst tool, values from the raster NDVI image were extracted to the point features selected at random and the value recorded to the attribute table (Appendix II). An average value of 10 points for each class was used for computation of vegetation fraction (f) (Equation 5). 
$f=\frac{1-i / s}{(1-i / s)-\mathrm{k}(1-\mathrm{i} / \mathrm{v})}$

Where;

$\mathrm{k}=\frac{\text { Rnirv-Rredv }}{\text { Rnirs-Rreds }}$

Where; (i) is NDVI of mixed vegetation and soil, (s) NDVI of pure soil (v) NDVI of fully vegetated. $R_{\text {nirv }}$ and $R_{\text {redv }}$ reflectance's in the NIR and Red bands of fully vegetated area, $R_{\text {nirs }}$ and $R_{\text {reds }}$ reflectance's in the NIR and Red bands of pure soil region and vegetation fraction (f).

\section{b) Emissivity computation}

Emissivity $(\epsilon)$ varies with wavelength and temperature with values ranging between 0 and 1 (Lillesand et al., 2008). Emissivity was computed for each image by averaging values for pure soil, fully vegetated area and mixed vegetation and soil. Vegetation fraction values were used in emissivity calculation (Equation 6). The first step in computation of emissivity was calculation of vegetation fraction which is the percentage of the vertical projection of vegetation canopy per unit area followed by temperature computation (Zhang et al., 2013; Qin et al., 2011). Appendix II illustrates emissivity computation for one Landsat scene.

$\epsilon=0.985 f+0.960(1-f)+0.06 f(1-f)$

\section{LST computation}

Band 6h (high gain) was used in LST computation because it is generally more sensitive to vegetation. After the radiance of the thermal image (6h) was calculated and emissivity, surface temperature was obtained from the inverse of the Planck function - Equation 7 (Zhang et al., 2013).

$L S T=\frac{\mathrm{K} 2}{\ln \left(\frac{K_{1} * \mathrm{E}}{\mathrm{L} \lambda}+1\right)}-273$ 


\section{Journal of Applied Sciences, Engineering and Technology for Development. Volume 2, Issue 1}

Where: (LST) Land surface temperatures in Celsius, $\left(\mathrm{L}_{\lambda}\right)$ spectral radiance in watts $\mathrm{m}^{-2} \mathrm{Sr}^{-1}$ $\mu \mathrm{m}^{-1}, \mathrm{~K} 1$ and $\mathrm{K} 2$ pre-launch calibration constants on the Landsat ETM+, K1=666.09 and k2= 1282.71, ( $\epsilon$ ) emissivity (Equation 6).

\section{Geology}

The geology of the study area was adopted from the geological map of Kenya at a scale 1:1 million which has 10 types of formations. The map was digitized and reclassified with help of experts through questionnaires to show formations which are associated with geothermal.

\section{Multi Criteria Analysis}

AHP is a decision making technique designed to select best alternatives evaluated from several criteria using fundamental scale (Table 4). The basic procedure of the AHP is to develop the ratings for each decision alternative for each criterion by comparing each factor with each other in pairwise comparison matrix, then normalization of the resulting matrix and calculating and checking the consistency ratio then calculating the weighted average (Saaty, 2008).Thematic layers were classified, standardised into three classes and AHP method was used for weighting various variables.

\section{RESULTS AND DISCUSSION}

\section{Environmental Suitability Indicators}

Areas with less than $15 \%$ slope were considered less costly for siting wells because the volume of drilling would be less compared to very steep areas. Areas with drainage density of less than 0.014 were considered not to be prone to flooding. Land use/cover map (LULC) was generated using per pixel supervised multispectral classification using the maximum likelihood algorithm Landsat ETM+ bands, 1, 2, 3, 4, 5 and 7 were used. Six classes were extracted namely, water, rangeland, forest, built up areas, agriculture and others. The datasets were modelled with Erdas model maker and ArcGIS Model Builder (Figure 4). 
Journal of Applied Sciences, Engineering and Technology for Development. Volume 2, Issue 1

Table 4: Fundamental Scale for pairwise comparisons. Source: Saaty, 2008.

\begin{tabular}{ll}
\hline Scale & Degree of preference \\
\hline $\mathbf{1}$ & Equal \\
$\mathbf{3}$ & importance \\
$\mathbf{5}$ & Moderate importance of one factor over other \\
$\mathbf{7}$ & Strong or essential importance \\
$\mathbf{9}$ & Very strong importance \\
$\mathbf{2 , 4 , 6 , 8}$ & Extreme importance \\
\hline
\end{tabular}

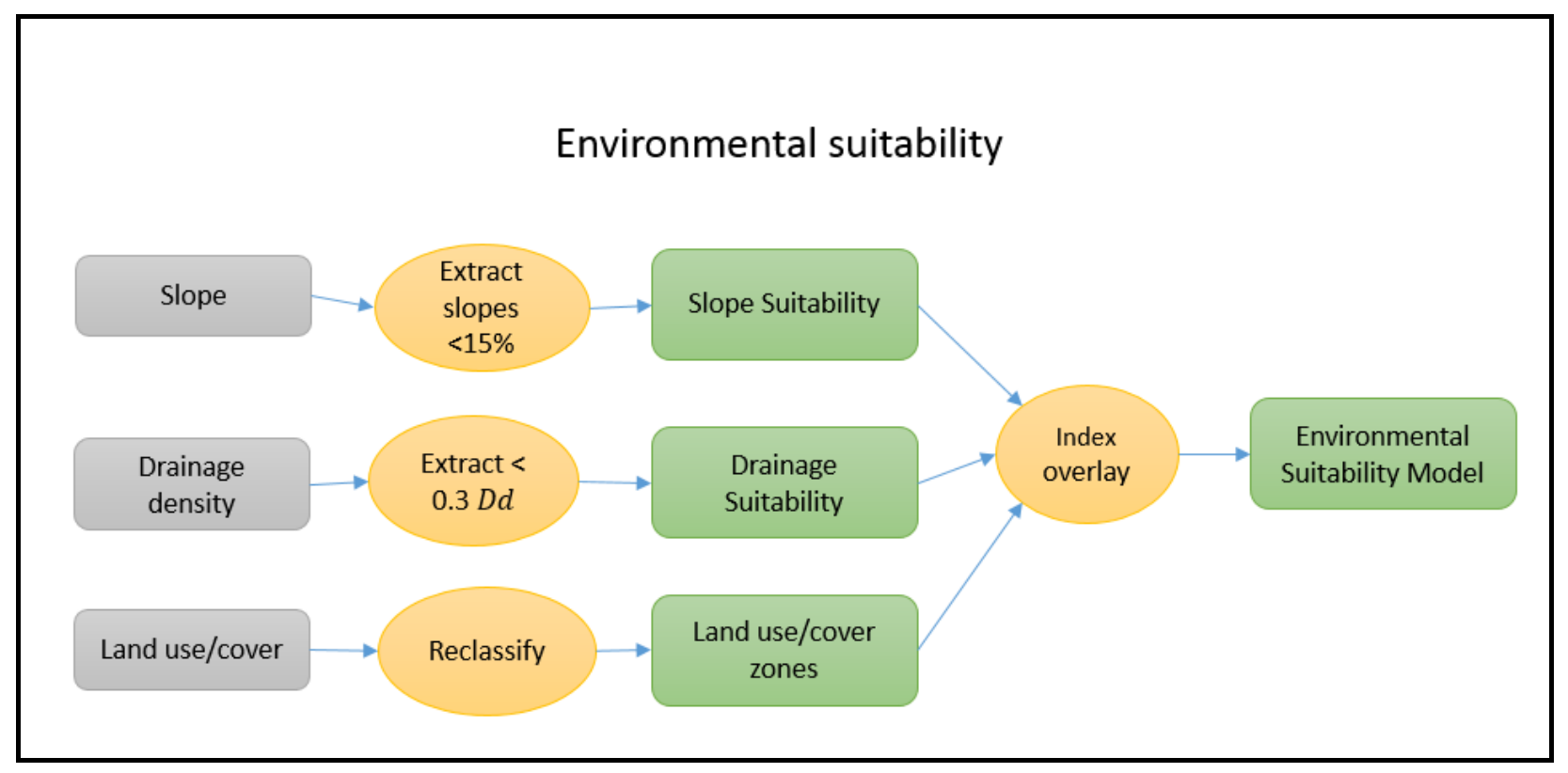

Figure 4: Environmental suitability model designed and developed from slope, drainage density and Land use/cover datasets.

The study area is generally flat with $80 \%$ of the area having slope less than $4 \%$ percentage slope thus making the area favourable for drilling wells (Figure 5a). The rift valley region is generally flat with some escarpments where the percentage slope is higher. The area has several lakes and rivers though not very dense drainage density which eliminates the risk of flooding for a larger area. The drainage density is heavier to the north where there is a water 
Journal of Applied Sciences, Engineering and Technology for Development. Volume 2, Issue 1

catchment area, the greater part of the study area has a drainage density of less than 0.014 which makes it good for well siting (Figure 5b).

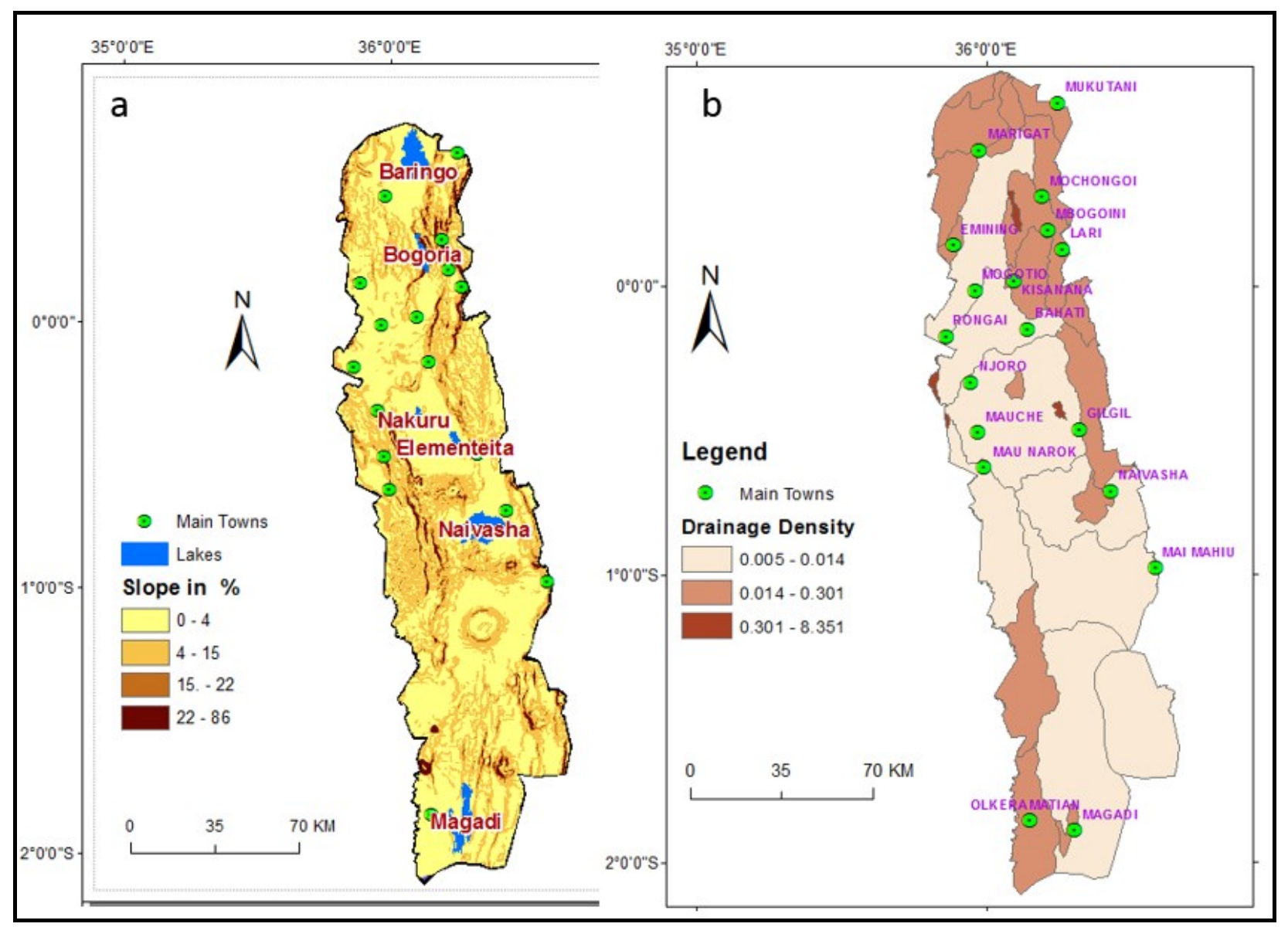

Figure 5: a) Thematic map showing slope of the study area in percentage and b) Drainage Density as computed from the drainage network derived from ASTER DEM

Rangeland is the dominant Land use/cover since most of the communities are pastoralists followed by agriculture due to subsistence farming with areas around Lake Naivasha practising commercialized agriculture by use of greenhouses because of the availability of fresh water (Figure 6). Built up areas were not well classified with small towns and shopping centres being left out during the classification resulting to lowest accuracy. 


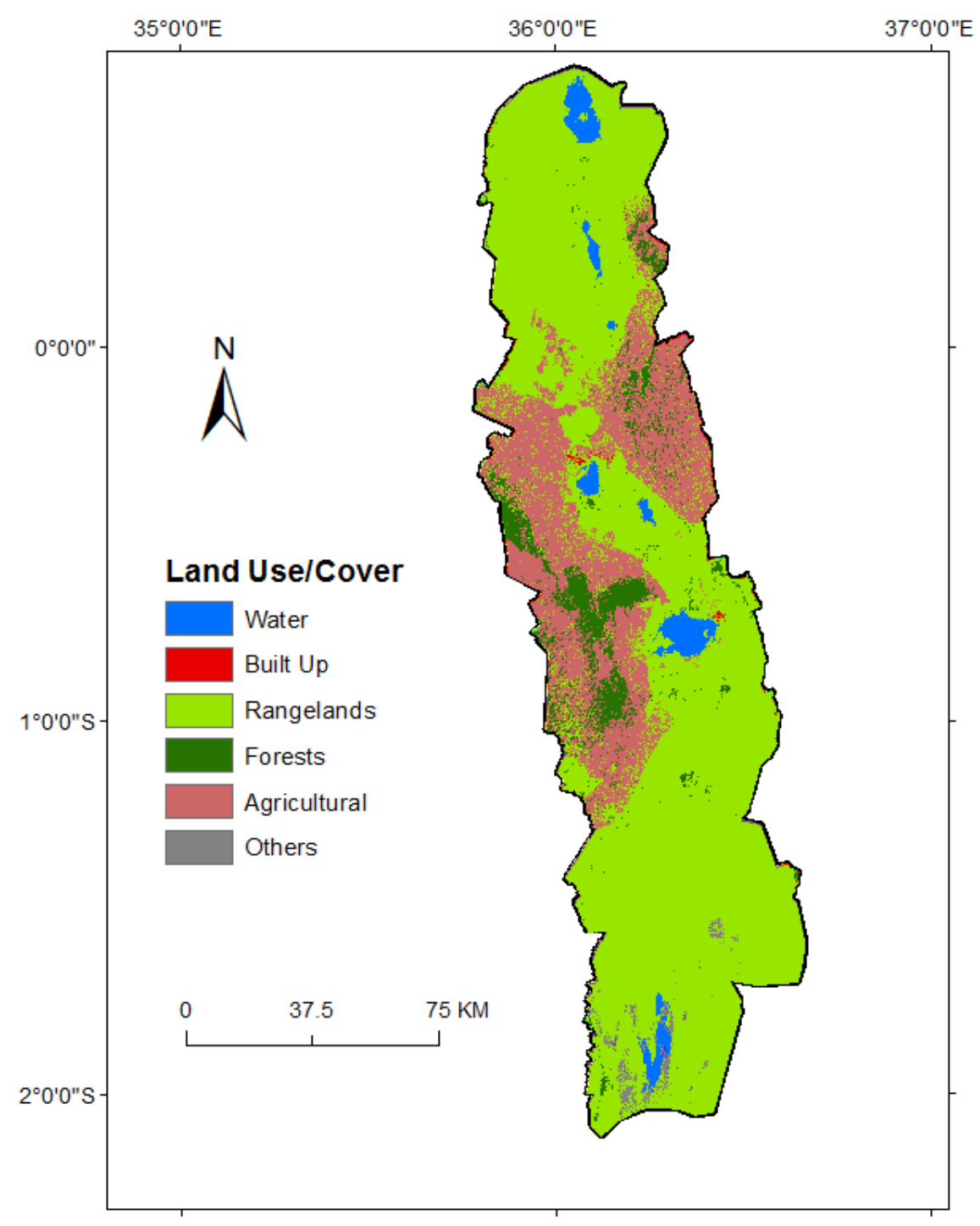

Figure 6: Land use/cover thematic map classified into 6 classes from Landsat 7 ETM+ using maximum likelihood algorithm.

The overall accuracy for classification was $75.8 \%$ with forest having over $90 \%$ while agricultural areas had lowest accuracy of $53.62 \%$ (Table 5). Kappa index which is a measure of how well the remote sensed classification agrees with the reference data was calculated and when Kappa index is greater than $80 \%$ then there is strong agreement between classified data and reference data (Congalton, 1991); for this classification 76\% accuracy was achieved.

Table 5: Accuracies of the classification results for Landsat ETM+ 
Journal of Applied Sciences, Engineering and Technology for Development. Volume 2, Issue 1

\begin{tabular}{|c|c|c|c|c|c|c|c|c|}
\hline Classified Data & Fores & $\begin{array}{l}\text { Rangel } \\
\text { ands }\end{array}$ & Agricult & Wetlan & $\begin{array}{l}\text { Water } \\
\text { Bodies }\end{array}$ & $\begin{array}{l}\text { Built } \\
\text { Up }\end{array}$ & $\begin{array}{l}\text { Bare } \\
\text { lands }\end{array}$ & Otherlands \\
\hline Forests $\quad$ l & 34 & 5 & 11 & 0 & 0 & 0 & 0 & 0 \\
\hline Rangelands & 0 & 41 & 6 & 2 & 0 & 0 & 0 & 1 \\
\hline Agricultural & 1 & 10 & 37 & 2 & 0 & 0 & 0 & 0 \\
\hline Wetlands & 0 & 1 & 6 & 35 & 7 & 0 & 0 & 1 \\
\hline Water Bodies & 0 & 0 & 0 & 2 & 46 & 0 & 0 & 2 \\
\hline Built Up & 0 & 0 & 8 & 0 & 0 & 32 & 0 & 10 \\
\hline Barelands & 0 & 0 & 1 & 1 & 0 & 4 & 39 & 5 \\
\hline Otherlands & 0 & 1 & 0 & 0 & 1 & 6 & 3 & 39 \\
\hline Total & 35 & 58 & 69 & 42 & 54 & 42 & 42 & 58 \\
\hline $\begin{array}{l}\text { Producers } \\
\text { Accuracy (\%) }\end{array}$ & 97.14 & 70.69 & 53.62 & 83.33 & 85.19 & 76.19 & 92.86 & 67.24 \\
\hline $\begin{array}{l}\text { Users Accuracy } \\
(\%)\end{array}$ & 68.00 & 82.00 & 74.00 & 70.00 & 92.00 & 64.00 & 78.00 & 78.00 \\
\hline Kappa & $\begin{array}{l}0.649 \\
3\end{array}$ & 0.7895 & 0.6858 & 0.6648 & 0.9075 & $\begin{array}{l}0.597 \\
8\end{array}$ & $\begin{array}{l}0.754 \\
2\end{array}$ & 0.7427 \\
\hline \multicolumn{9}{|c|}{ Overall Classification Accuracy $=75.75 \%$} \\
\hline Overall Kappa St & tistics & .7229 & & & & & & \\
\hline
\end{tabular}

\section{Land Surface Temperature Indicators}

LST was derived from Landsat thermal band while considering variability of surface emissivity due to variations in vegetation, soil moisture and topography (Figure 7).

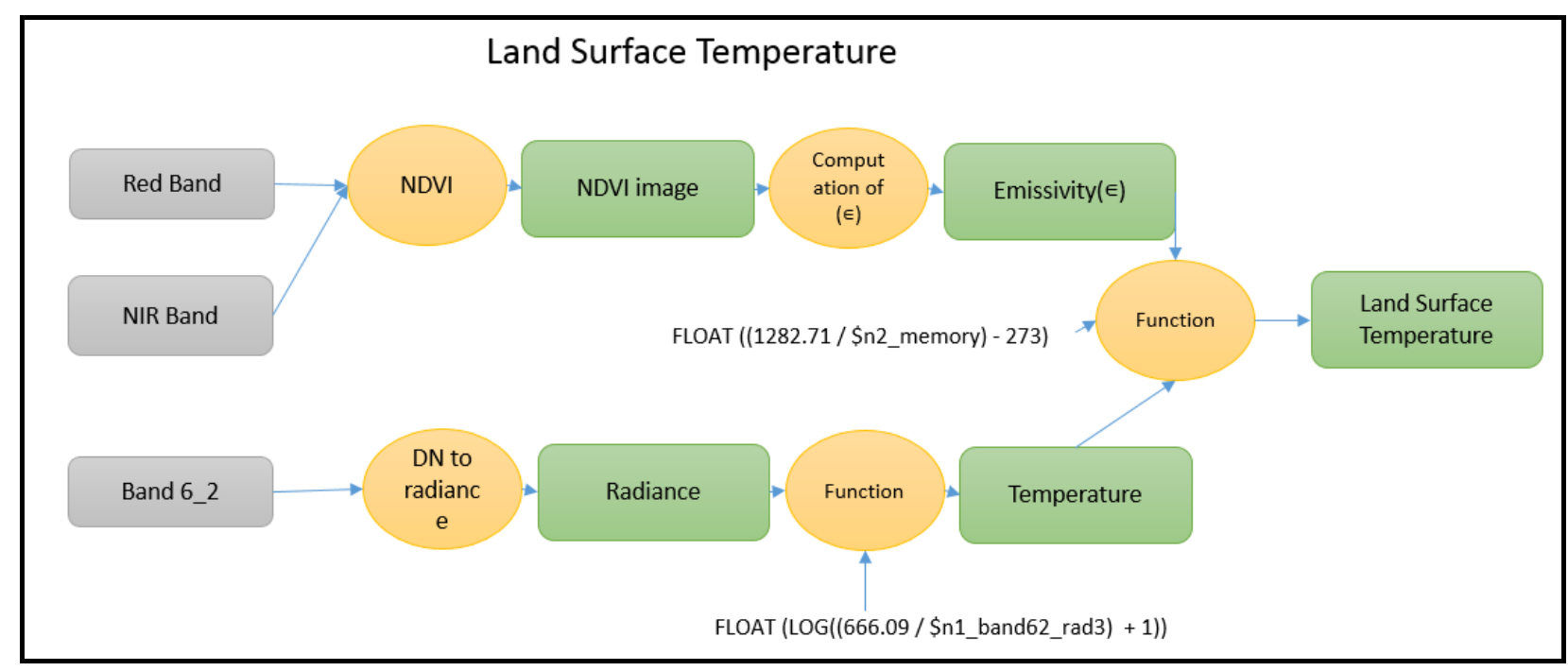

Figure 7: Land Surface Temperature model derived to show heat anomalies associated with geothermal energy 
Radiance method for Land Surface Temperature computation was adopted and estimation of emissivity was based on NDVI estimation for pure soil, pure vegetation and mixed vegetation. The values for NDVI for pure vegetation for image $169 / 061$ was 0.23 , pure soil was -0.10 and mixed pixel was -0.07 .

The coolest areas have 26 degrees Celsius and the highest being 51 degrees Celsius (Figure 8). The coolest areas are around the water bodies and highland areas like the calderas. The area around Lake Magadi recorded the highest temperatures as well as the area around Lake Baringo. 
Journal of Applied Sciences, Engineering and Technology for Development. Volume 2, Issue 1

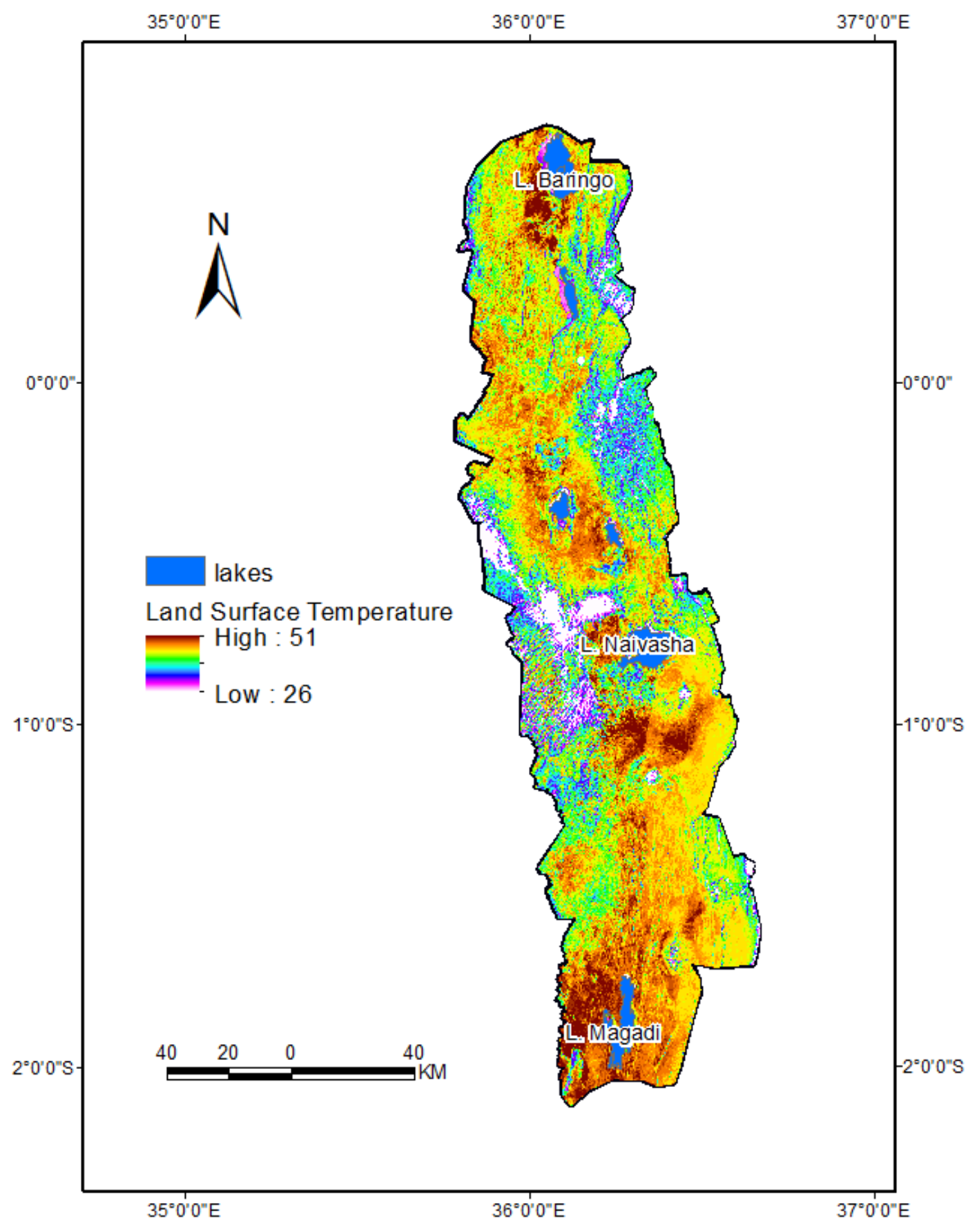

Figure 8: Land Surface Temperature thematic map derived from Landsat thermal band. 
Journal of Applied Sciences, Engineering and Technology for Development. Volume 2, Issue 1

\section{Geological Indicators}

Geology data was classified from the geological map of Kenya using geothermal expert opinion (Figure 9).

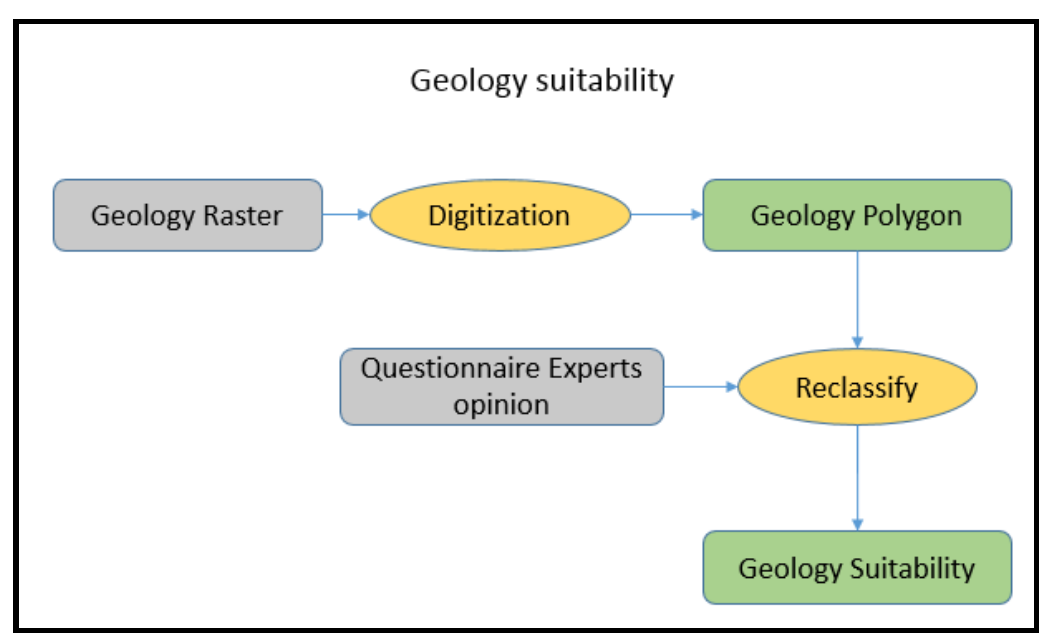

Figure 9: Geology suitability model used to rank the geology type associated with geothermal energy by inclusion of the expert opinion.

The geology of the area is characterized by quaternary deposits mainly the pyroclastic rocks, youngest of the volcanic materials include rhyolites, trachytes, basalts, phonolites, and pyroclastics (Figure 10). 
Journal of Applied Sciences, Engineering and Technology for Development. Volume 2, Issue 1

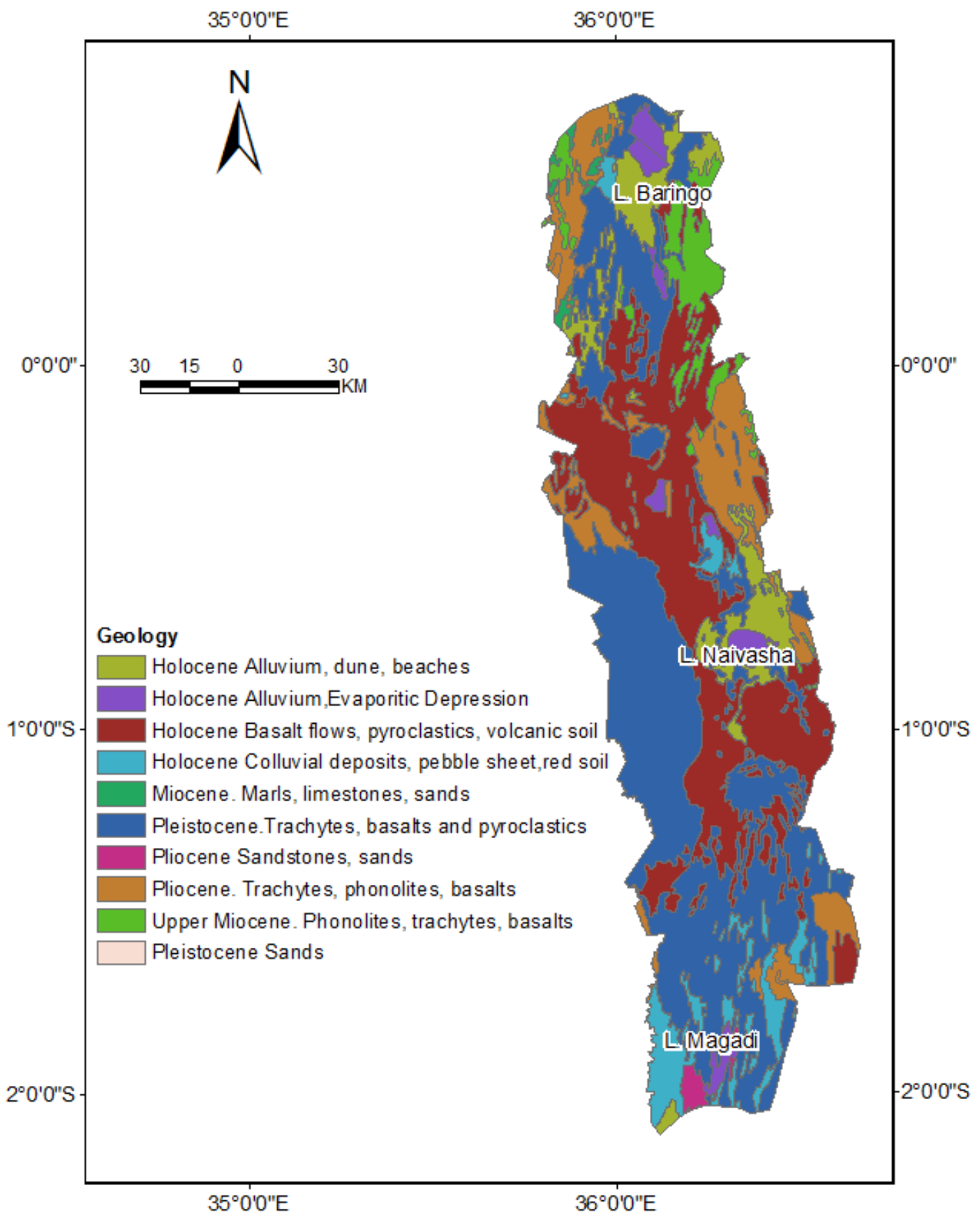

Figure 10: Geology of the study area. Source: Geological map of Kenya 


\section{Journal of Applied Sciences, Engineering and Technology for Development. Volume 2, Issue 1}

The geological information was extracted into the table below and shared with experts in the geothermal sector to indicate which geological formation would be classified as high geothermal potential, moderate geothermal potential and low geothermal potential (Figure $11)$.

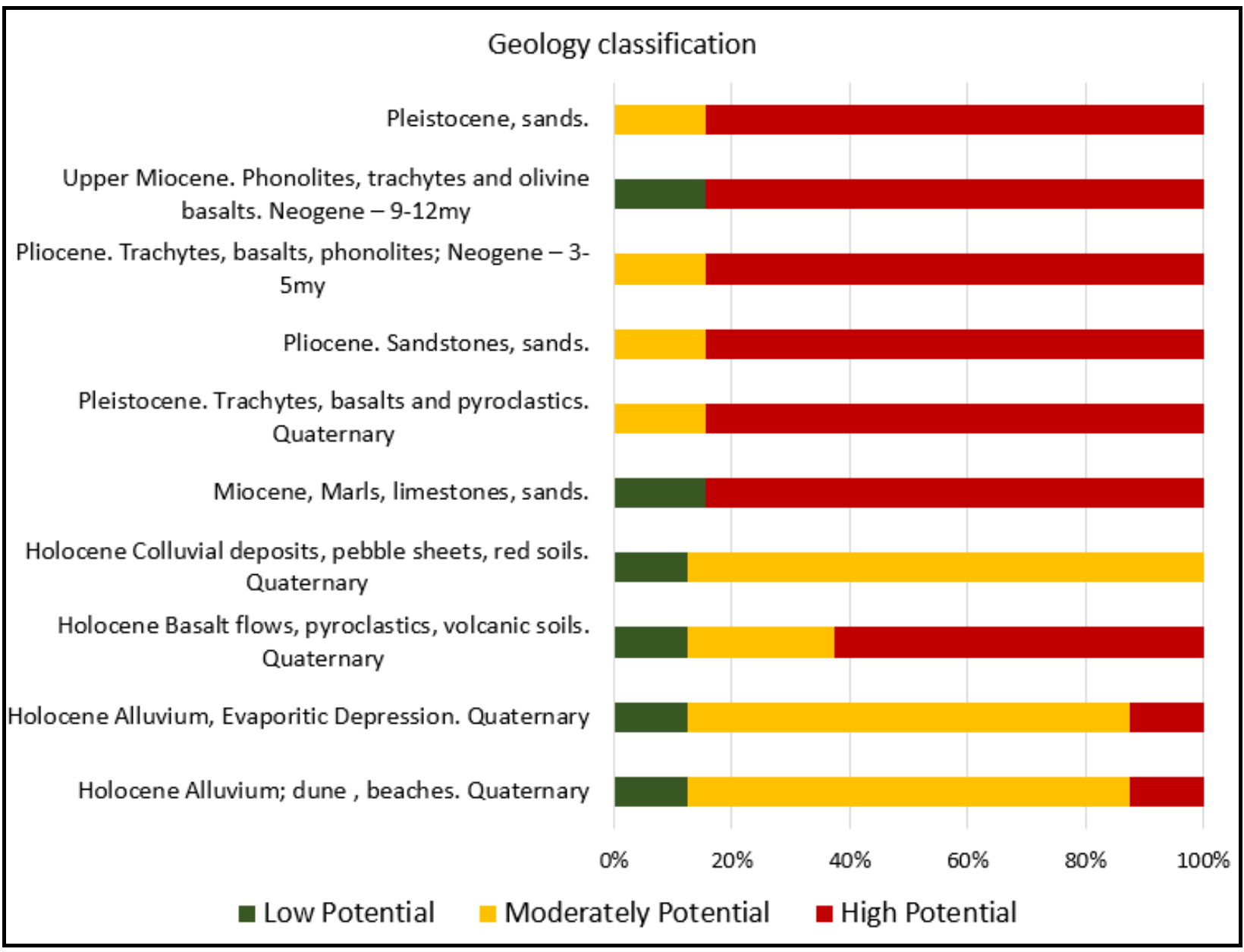

Figure 11: Geology classification analysed through expert's opinion

The multi criteria decision was used to combine the different variables by incorporating expert's opinion and scaling the judgement using the AHP method as shown in Table 6 .

With consistency ratio of 0.052 , shows that the judgments were acceptable since it's below 0.1 which is the acceptable range according to Saaty, 2008. Sub criteria analysis was done to cater for the different levels of each map. For geology areas which were classified as high potential were given value 9 while moderate potential areas were given value 3 . 
Journal of Applied Sciences, Engineering and Technology for Development. Volume 2, Issue 1

Table 6: AHP weighting

\begin{tabular}{lllll}
\hline & Geology & $\begin{array}{l}\text { Land Surface } \\
\text { Temperature }\end{array}$ & $\begin{array}{l}\text { Environmental } \\
\text { Suitability }\end{array}$ & $\begin{array}{c}\text { AHP } \\
\text { Weight }\end{array}$ \\
\hline Geology & 1 & 3 & 9 & 66.306 \\
Land Surface Temperature & 0.333 & 1 & 6 & 27.847 \\
Environmental Suitability & 0.111 & 0.167 & 1 & 5.847 \\
Consistency Ratio & & 0.052 & & \\
\hline
\end{tabular}

Knowledge of the surface emissivity is important for determining the radiation balance at the land surface. Emitted long wave radiation is mainly affected by the surface emissivity of land cover. This was important component when deriving land surface temperature and was considered (Qin, 2011). Geology data was classified by expert's opinion as the most important of the three models. The results of the environmental suitability, LST and geology integration models were overlain by AHP analyses and suitable areas for geothermal well sites were defined and prioritized (Figure 12). 
Journal of Applied Sciences, Engineering and Technology for Development. Volume 2, Issue 1

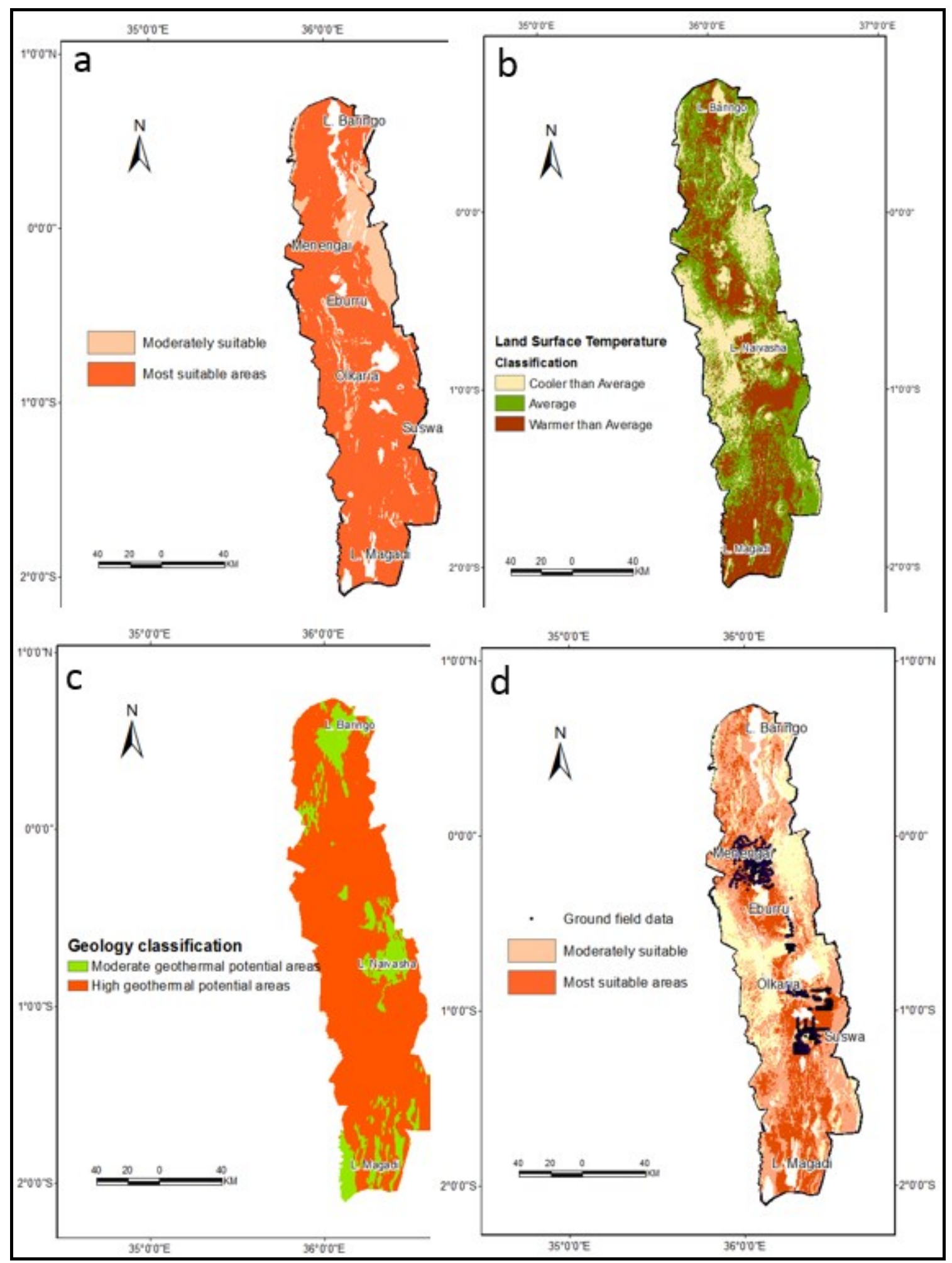

Figure 12: a) Environmental suitability, b) classified Land Surface Temperature, c) Geology classification and d) Geothermal potential areas. 


\section{Journal of Applied Sciences, Engineering and Technology for Development. Volume 2, Issue 1}

In situ ground surface temperature (GST) measurements for Eburru, and Suswa sites were used to validate the model derived Land Surface Temperature (LST) computed using the Landsat thermal band. GST data was obtained using hand held thermometers during the field visits, and their corresponding ground coordinates recorded using hand held GPS. The data provided was for near time interval though not the exact data. This data was mapped and overlaid on the calculated LST. GIS spatial analyst tool was used to extract LST values for the same points and plotted for analysis. The corresponding LST and GST were then plotted on scatter plots for the four sites. This comparison is presented in Figure 13

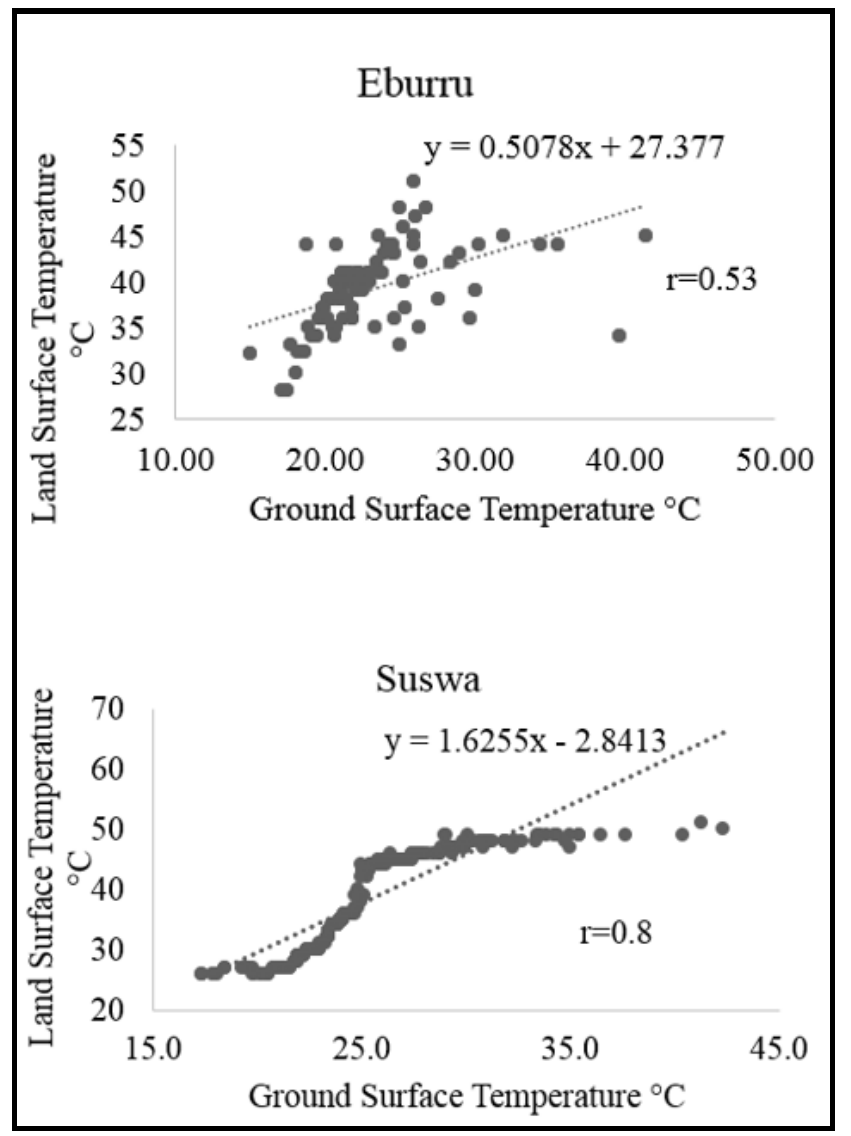

Figure 13: Comparison of derived LST and measured LST on the ground for Eburru and Suswa

Validation of geothermal potential map 


\section{Journal of Applied Sciences, Engineering and Technology for Development. Volume 2, Issue 1}

Validation of the results was first done by visual interpretation where ground survey data was overlaid on the geothermal potential map to check correlation. Since detailed ground surveys have been done at Menengai, Eburru and Suswa and their results published, this formed part of validation data as well as coordinated information on sampled fumaroles and other survey data collected (Kiende \& Kandie, 2015; Omenda, 2007; Omenda \& Karingithi, 1993; Mibei, 2012; Wanjohi, 2012; Njue, 2013).

GIS Spatial Analyst tool for extracting multi value to points was then used to extract values from the geothermal potential map to the survey points and analysis done on which category the ground data belonged in respect to the three zones of high potential, moderately potential and low potential geothermal areas. Several GPS locations and geochemical data were recorded (Menengai 344, Eburru 99 and Suswa 229) the data was available for validation of the remote sensing methodology.

At Menengai the geochemistry data was provided for ground truthing from radon and carbon dioxide in soil gas. It was observed that there were high radon-222 counts predominant and high carbon dioxide values were encountered close to fumaroles which suggest that there is a direct pathway from the magmatic heat sources and high heat flux. When this data was plotted on the geothermal potential map, it was classified as high potential zone (Figure 14). 


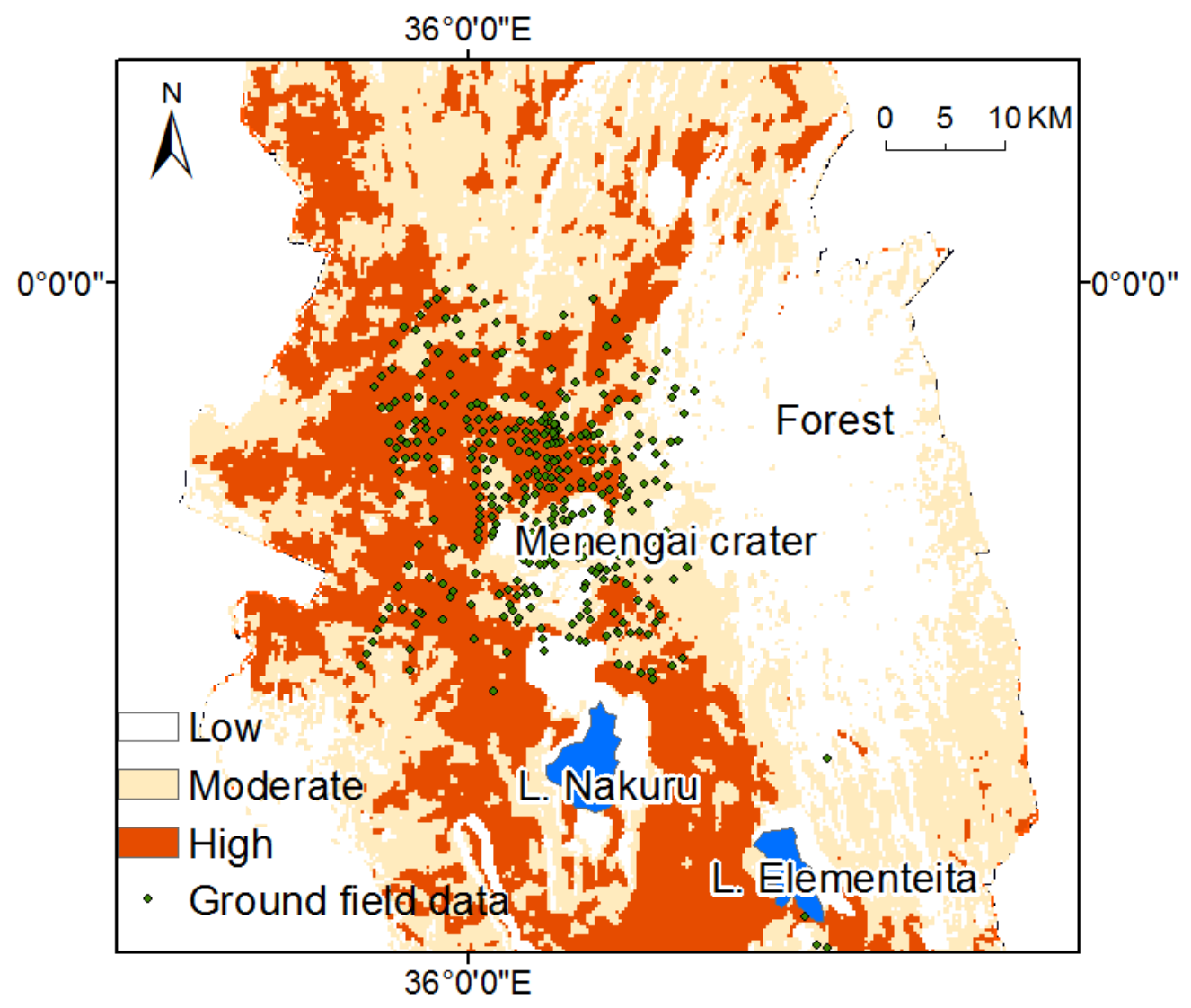

Figure 14: Menengai geothermal exploration potential map showing areas of high, moderate and low geothermal potential, modelled from GIS and Remote Sensing method.

It is observed that the area within the caldera for Menengai was classified as low geothermal potential area although survey methods reveal otherwise, this could be because the Land surface Temperatures were low as derived from the Landsat imagery but further research could be done. The other area that is classified as low potential is the forest area which could be because of the low temperature and type of vegetation. Ground survey data for Menengai when compared with geothermal potential map showed good correlation where $52 \%$ ground survey points are in the category of high geothermal potential areas, $38 \%$ in the moderate potential areas and $10 \%$ in the low potential area category (Figure 15). 


\section{Journal of Applied Sciences, Engineering and Technology for Development. Volume 2, Issue 1}

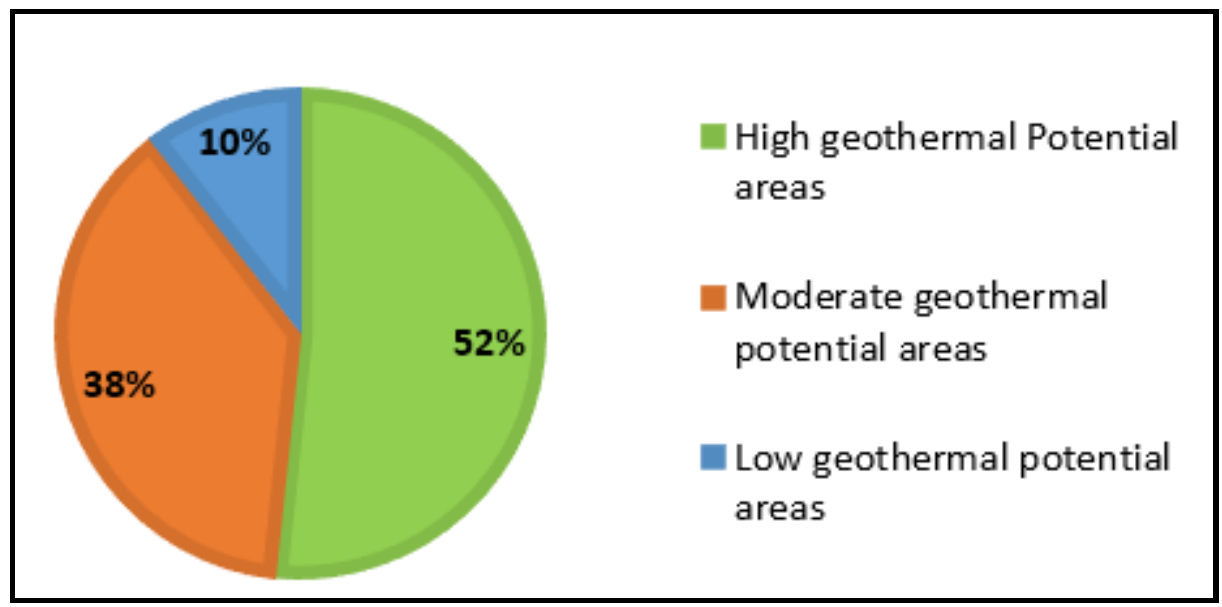

Figure 15: Analysis correlating Menengai high geothermal potential areas mapped from ground survey methods and data derived from the GIS and Remote Sensing.

Longonot geothermal exploration has been carried out by Africa Geothermal International Ltd (AGIL) which has estimated geothermal power of $150 \mathrm{MWe}$ and they have provided report on the geophysical, geochemical and geological surveys (Alexander et al., 2011). The caldera and crater represents viable heat sources, eruptive centers are also present according to survey analysis but using the GIS and Remote Sensing the calderas are classified as moderate geothermal potential (Figure 4.28). This would be an area for further research. Geophysical analyses show that there is a large shallow conductor on the southern part of the volcano. High ground temperatures were observed above average and high counts of radon and carbon dioxide gas. The survey data was plotted on the geothermal map with most of the ground survey data mapping in the high geothermal potential areas.

Akira and Maai Mahiu ranches and Longonot farm make up a big part of Longonot. Longonot National Park covers the summit crater and the surrounding area. The area around Longonot is marked by active and extinct geothermal manifestations. The active manifestations occur in form of fumaroles, altered grounds, warm grounds, and sulphur and silica deposition. Extinct manifestations are indicated by presence of altered grounds to brick red/ grey clays and silica deposition. Geothermal potential maps reveal the area around the Mai Mahiu Ranch to be high potential as well as the area north of the Longonot Caldera (Figure 16). 
Journal of Applied Sciences, Engineering and Technology for Development. Volume 2, Issue 1

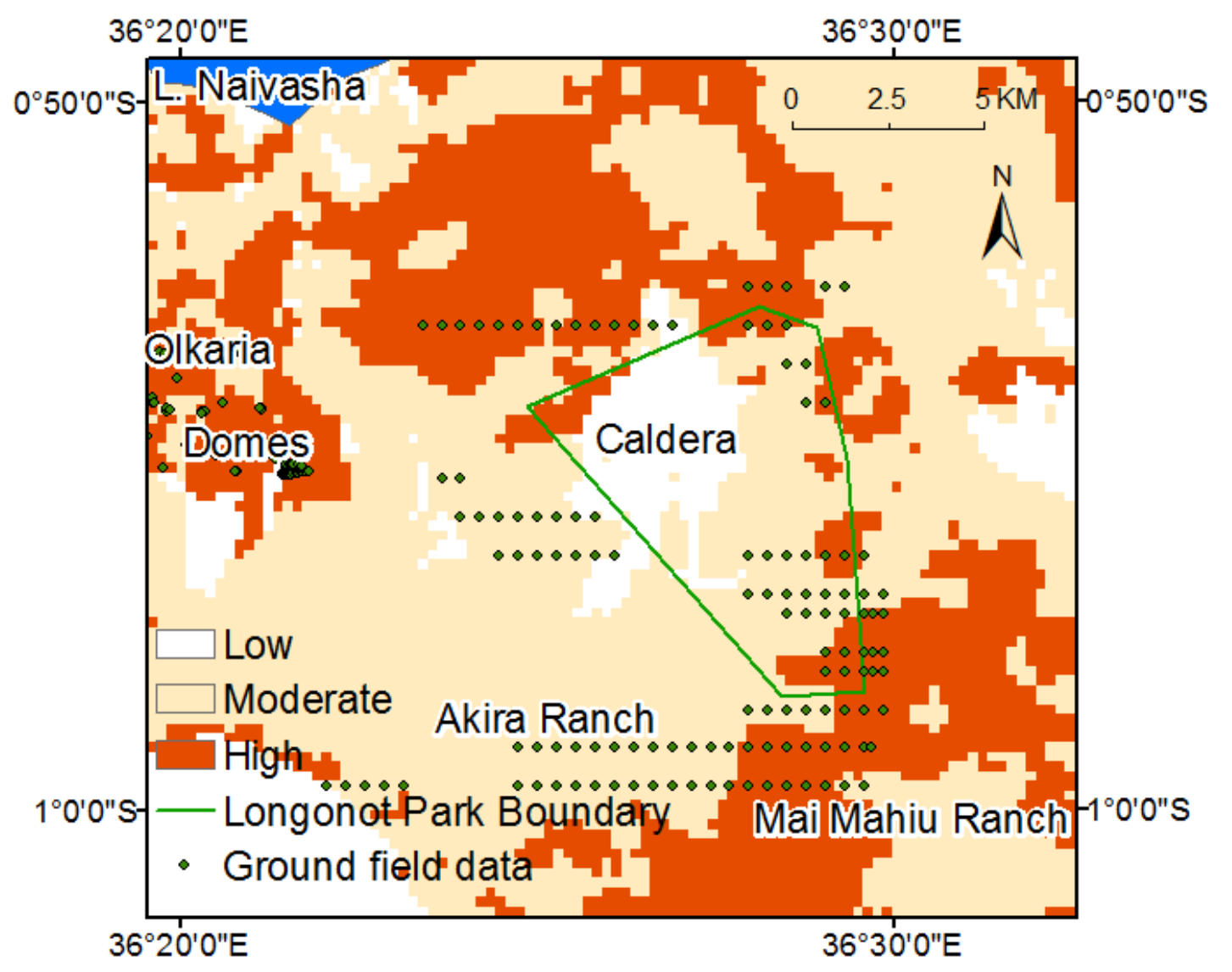

Figure 16: Longonot geothermal exploration potential map showing areas of high, moderate and low geothermal potential modelled from GIS and Remote Sensing method.

Within the Caldera it's mapped as low potential area whereas from the geo scientific methods this is a high potential area. $81 \%$ of ground survey data mapped in the high potential area, $17 \%$ in the moderate geothermal potential area and $2 \%$ in the low geothermal potential area (Figure 17). 


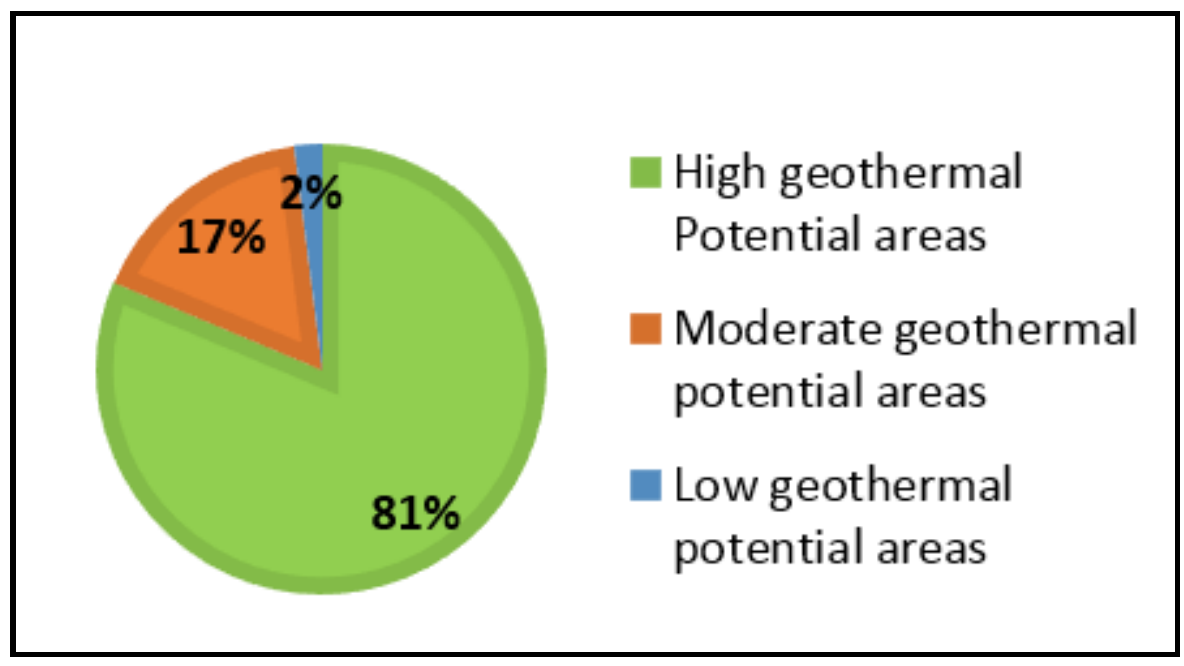

Figure 17: Analysis correlating Longonot high geothermal potential areas mapped from ground survey methods and data derived from the GIS and Remote Sensing.

Suswa volcano has inner and outer caldera. The reservoir temperature of Suswa resource is about $250^{\circ} \mathrm{C}$ with the heat source being about $7 \mathrm{~km}$ deep under the caldera (Omenda, 2007). The chemical data correlate well with the geology data with the gas geo-thermometers showing origin of hot temperatures of more than $250^{\circ} \mathrm{C}$.

Suswa is a large caldera volcano with thermal surface manifestations in form of fumaroles, altered grounds, and mineral deposition. Active and extinct fumaroles occur along faults around the outer and the inner caldera. Altered grounds are scattered within the area and characterised by reddish alteration to clays and sulphur and or silica deposition. Geothermal potential map of Suswa reveal more potential areas to the East of the caldera and also around Olasiti (Figure 18). 
Journal of Applied Sciences, Engineering and Technology for Development. Volume 2, Issue 1

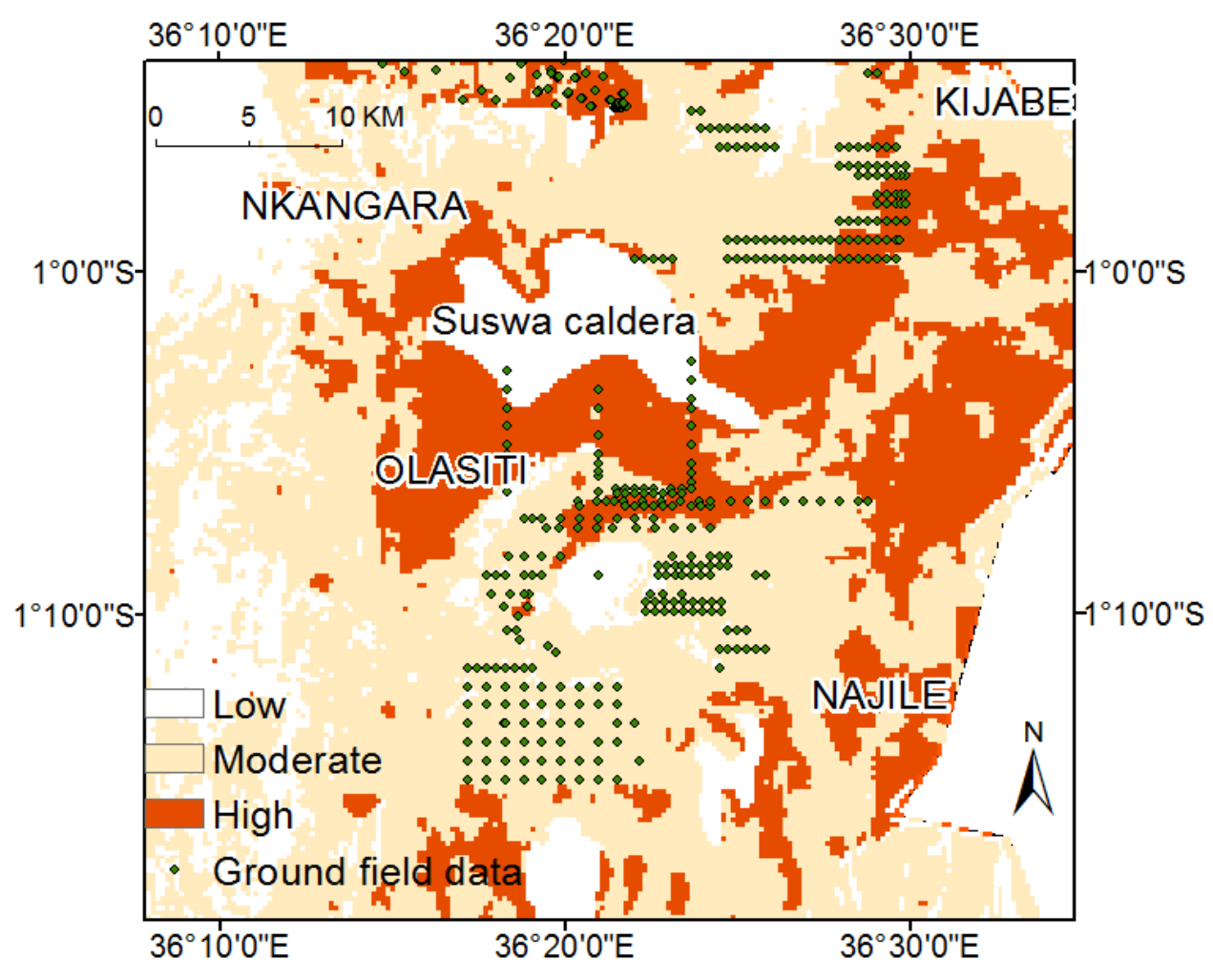

Figure 18: Suswa geothermal exploration potential map showing areas of high, moderate and low geothermal potential modelled from GIS and Remote Sensing method.

Suswa caldera maps in the low geothermal potential category due to low temperatures within. $53 \%$ of the ground survey data fell within the high geothermal potential category with $44 \%$ mapping in the moderate geothermal potential areas and 3\% in the low geothermal potential areas (Figure 19).

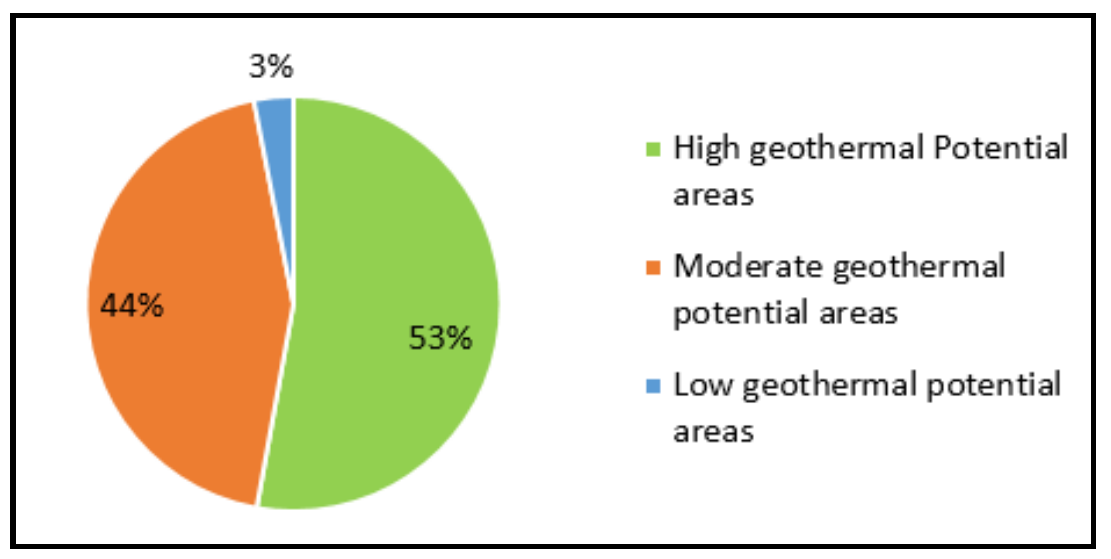

Figure 19: Analysis correlating Suswa high geothermal potential areas mapped from ground survey methods and data derived from the GIS and Remote Sensing. 


\section{Journal of Applied Sciences, Engineering and Technology for Development. Volume 2, Issue 1}

\section{CONCLUSION}

From this research we proposed an approach for deriving geothermal indicators using remote sensing and GIS technology to classify geothermal potential areas by environmental model, LST and geology. In addition expert opinion was incorporated to enable weighting of different parameters while combining them using AHP.LST and geology layers were used to show the geothermal anomalous areas, while the environmental suitability model helped to narrow down to specific areas suitable for drilling.

The approach modelled geothermal indicators within the GIS and remote sensing environment and resulted into generating geothermal potential favourability map of part of the Kenyan rift ranked into three classes low, moderate and high geothermal potential favourability areas.

The research focused on a) choice of geothermal indictors that could be mapped using low cost methods of remote sensing and GIS, b) methodology designed to derive the parameters for modelling specific to the study area and c) weighting and ranking criteria. The model for geothermal exploration is flexible and could be applied to other parts of Kenya or elsewhere with minimal customization to adapt to local areas.

The geothermal favourability map obtained shows areas with highest probability of being productive if wells are drilled there. It also shows areas with potential geothermal resource with a good agreement (over 50\%) where physical manifestations have been sited, this methodology would be very applicable for countries which have not exploited their geothermal resource. The map could also be very useful as a guide to geo scientist as they do detailed exploration because they would narrow down to specific areas thus reducing cost of exploration. The model developed in this study could be used in other countries with little customization to local environment. 


\section{Journal of Applied Sciences, Engineering and Technology for Development. Volume 2, Issue 1}

\section{REFERENCES}

Alexander, K. B., Ussher, G., \& Merz, S. K. (2011). Geothermal Resource Assessment for Mt. Longonot, Central Rift Valley, Kenya. Geothermal Resources Council Transactions, 35, 1147-1154.

Anderson, James R., Ernest E. Hardy, John T. Roach, and Richard E. W.(1976). A Land Use and Land Cover Classification System For Use With Remote Sensor Data. USGS Professional Paper 964. A revision of the land use classification system as presented in the USGS Circular 671.

Congalton, R.G. \& Green, K. (2009). Assessing the Accuracy of Remotely sensed Data: Principles and Practices. CRC press, New York.

Congalton, R. G. (1991). A review of assessing the accuracy of classifications of remotely sensed data. Remote Sensing of Environment, 37(1), 35-46.

KenGen report (2017). http://www.kengen.co.ke/?q=content/geothermal-plants; accessed 27.07.2017.

Kenya Energy (2017). https://www.globallegalinsights.com/practice-areas/energy/globallegal-insights---energy-5th-ed./kenya. Accessed 27.07.2017

Kiende, R., \& Kandie, R. (2015). Structural Geology of Eburru Volcano and Badlands Geothermal Prospects in Kenya. Paper presented at the Fourtieth Workshop on Geothermal Reservoir Engineering.

Lillesand, T.M., Kiefer, R. W. \& Chipman, J.W. (2008). Remote Sensing and Image Interpretation. John Wiley \& Sons, New York, U.S.A.

Macharia, M.W, Gachari, M.K, Kuria, D.N and Mariita N.O.(2017) Low cost geothermal energy indicators and exploration methods in Kenya. Journal of Geography and Regional Planning. Vol.10(9), pp. 254-265.DOI: 10.5897/JGRP2017.0643.

Macharia,M. Lung,T and Schaab,G (2013).Extending Landsat based land use/cover time series after May 2003 for tropic rain forest areas in East Africa. Journal of Applied Sciences, Engineering and Technology for Development Vol. 1, No. 1, 35 - 49.

Mia, M.B.,Bromley C.J., Fujimitsu, Y.(2012). Monitoring heat flux using Landsat TM/ETM+ thermal infrared data, A case study at Karapiti ('Craters of the Moon') thermal area, New Zealand. Journal of Volcanology and Geothermal Research 235-236; 1-10.

Mibei, G. (2012). Geology and hydrothermal alteration of Menegai geothermal field. Case study: Wells MW-04 and MW-05. Geothermal Training in Iceland, Technical Report(21), 437-465.

NASA, (2009). Landsat 7 Science Data Users' Handbook.

Njue, L. M. (2014). Geological field mapping. 001374011.

Noorollahi, Y., Itoi, R., Fujii, H., \& Tanaka, T. (2007). GIS model for geothermal resource exploration in Akita and Iwate prefectures, northern Japan. Computers \& Geosciences, 33(8), 1008-1021. doi:http://dx.doi.org/10.1016/j.cageo.2006.11.006

Noorollahi, Y., Itoi, R., Fujii, H., \& Tanaka, T. (2008). GIS integration model for geothermal exploration and well siting. Geothermics, 37(2), 107-131.

Omenda, P., \& Simiyu, S. (2015). Country update report for Kenya 2010-2014. Proceedings World Geothermal.

MACHARIA, et al.: A GIS-Based Approach for Exploring Geothermal Resources Along Part of the Kenyan Rift. 


\section{Journal of Applied Sciences, Engineering and Technology for Development. Volume 2, Issue 1}

Omenda, P. A. (2007). Status of geothermal exploration in Kenya and future plans for its development. Short Course II on Surface Exploration for Geothermal Resources, organized by UNU-GTP and KenGen, at Lake Naivasha, Kenya, 2-17.

Omenda, P. A., \& Karingithi, C. W. (1993). Hydrothermal model of Eburru geothermal field, Kenya. Paper presented at the The 1993 Annual Meeting on Utilities and Geothermal: An Emerging Partnership, Burlingame, CA, USA, 10/10-13/93.

Pürschel, M., Gloaguen R., Stadler S. (2013).Geothermal activities in the Main Ethiopian Rift: Hydrogeochemical characterization of geothermal waters and geothermometry applications (Dofan-Fantale, Gergede-Sodere, Aluto-Langano). Geothermics 47: 1-12. doi:https://doi.org/10.1016/j.geothermics.2007.12.001

Qin, Q., Zhang N.,Nan, P., Chai, L.(2011).Geothermal area detection using Landsat ETM+ thermal infrared data and its mechanistic analysis - A case study in Tengchong, China. International Journal of Applied Earth Observation and Geoinformation 13: 552-559.

Reeves, R., \& Rae, L. (2016). Changes in aerial thermal infrared signature over the Rotorua Geothermal Field, New Zealand: 1990-2014. Geothermics, 64, 262-270. doi:http://dx.doi.org/10.1016/j.geothermics.2016.06.007

Ren21. (2017). Renewables 2017: Global status report. Washington, DC: Worldwatch Institute.

Rotich, A. K. (2016). KenGen geothermal development status and future expansion plants. Paper presented at the Proceedings, 6th African Rift Geothermal Conference, Addis Ababa, Ethiopia, 2nd-4th November.

Saaty, T.L. (2008).Decision making with the analytic hierarchy process. Int. J. Services Sciences, Vol. 1, No. 1, pp.83-98.

Sadeghi, B., \& Khalajmasoumi, M. (2015). A futuristic review for evaluation of geothermal potentials using fuzzy logic and binary index overlay in GIS environment. Renewable and Sustainable Energy Reviews, 43, 818-831. doi:http://dx.doi.org/10.1016/j.rser.2014.11.079.

Shako, L., \& Wamalwa, A. (2014). GIS Applications in Heat Source Mapping in Menengai Geothermal Field. Paper presented at the Proceedings of the 5th African Rift Geothermal Conference.

Simiyu, S. M. (2010). Status of geothermal exploration in Kenya and future plans for its development. Paper presented at the Proceedings world geothermal congress.

Trumpy, E., Donato, A., Gianelli, G., Gola, G., Minissale, A., Montanari, D., and Manzella, A. (2015). Data integration and favourability maps for exploring geothermal systems in Sicily, southern Italy. Geothermics, 56, 1-16. doi:http://dx.doi.org/10.1016/j.geothermics.2015.03.004

Tufekci, N., Suzen, M.L., Gulec, N.(2010). GIS based geothermal potential assessment: a case study from Western Anatolia, Turkey. Energy 35 (1), 246-261.

Wamalwa, L. W. (2011). Multi-Criteria Suitability Modelling for Geothermal Exploration Wells Siting - A Case Study of the Silali Geothermal Prospect, North Rift Kenya GRC Transactions, Vol. 35,.

Wanjohi, A. W. (2013). Geophysical field mapping. Macmillan Publishers.

MACHARIA, et al.: A GIS-Based Approach for Exploring Geothermal Resources Along Part of the Kenyan Rift. 
Yalcin, M., \& Kilic Gul, F. (2017). A GIS-based multi criteria decision analysis approach for exploring geothermal resources: Akarcay basin (Afyonkarahisar). Geothermics, 67, 18-28. doi:http://dx.doi.org/10.1016/j.geothermics.2017.01.002

Zhang Y., Inakwu O.A. Odeh \& Elnazir Ramadan (2013) Assessment of land surface temperature in relation to landscape metrics and fractional vegetation cover in an urban/peri-urban region using Landsat data, International Journal of Remote Sensing, 34:1, 168-189. 